NBER WORKING PAPER SERIES

\title{
FOREIGN OWNERSHIP AND FIRM PERFORMANCE: EMERGING-MARKET ACQUISITIONS IN THE UNITED STATES
}

\author{
Anusha Chari \\ Wenjie Chen \\ Kathryn M.E. Dominguez \\ Working Paper 14786 \\ http://www.nber.org/papers/w14786
}

\author{
NATIONAL BUREAU OF ECONOMIC RESEARCH \\ 1050 Massachusetts Avenue \\ Cambridge, MA 02138 \\ March 2009
}

We thank Patricia Dechow, Jeff Smith, Jim Levinsohn, James Hines, Paolo Pasquariello, Matias Busso, Taryn Dinkelman, Dean Yang, Nirvikar Singh, and participants in the UM Development seminar, the UM IPC lunch group, the NIPFP conference at the Indian Ministry of Finance, the Australian Treasury, the Reserve Bank of Australia, and North Carolina State University for helpful comments and advice. We are grateful to the International Policy Center at the Ford School of Public Policy for financial support. The views expressed herein are those of the author(s) and do not necessarily reflect the views of the National Bureau of Economic Research.

NBER working papers are circulated for discussion and comment purposes. They have not been peerreviewed or been subject to the review by the NBER Board of Directors that accompanies official NBER publications.

(C) 2009 by Anusha Chari, Wenjie Chen, and Kathryn M.E. Dominguez. All rights reserved. Short sections of text, not to exceed two paragraphs, may be quoted without explicit permission provided that full credit, including (C) notice, is given to the source. 
Foreign Ownership and Firm Performance: Emerging-Market Acquisitions in the United States Anusha Chari, Wenjie Chen, and Kathryn M.E. Dominguez

NBER Working Paper No. 14786

March 2009, Revised May 2009

JEL No. F21,F23,G34

\begin{abstract}
$\underline{\text { ABSTRACT }}$
This paper examines the recent upsurge in foreign acquisitions of U.S. firms, specifically focusing on acquisitions made by firms located in emerging markets. Neoclassical theory predicts that, on net, capital should flow from countries that are capital-abundant to countries that are capital-scarce. Yet increasingly emerging market firms are acquiring assets in developed countries. Using transaction-specific acquisition data and firm-level accounting data we evaluate the post-acquisition performance of publicly traded U.S. firms that have been acquired by firms from emerging markets over the period 1980-2007. Our empirical methodology uses a difference-in-differences approach combined with propensity score matching to create an appropriate control group of non-acquired firms. The results suggest that emerging country acquirers tend to choose U.S. targets that are larger in size (measured as sales, total assets and employment), relative to matched non-acquired U.S. firms before the acquisition year. In the years following the acquisition, sales and employment decline while profitability rises, suggesting significant restructuring of the target firms.
\end{abstract}

Anusha Chari

301 Gardner Hall

CB\#3305, Department of Economics

University of North Carolina at Chapel Hill

Chapel Hill, NC 27599

and NBER

achari@unc.edu

Wenjie Chen

Department of Economics

Lorch Hall

University of Michigan

Ann Arbor, MI 48109

wenjiec@umich.edu
Kathryn M.E. Dominguez

University of Michigan

Department of Economics and Ford School

Weill Hall

Ann Arbor, MI 48109

and NBER

kathrynd@umich.edu 


\section{Introduction}

This paper examines the recent upsurge in foreign acquisitions of U.S. firms, specifically focusing on acquisitions made by firms located in emerging markets. Neoclassical theory predicts that, on net, capital should flow from countries that are capital-abundant to countries that are capital-scarce. ${ }^{1}$ Yet increasingly emerging-market firms are acquiring assets in the developed world. In particular, the recent spate of cross-border acquisitions by Indian and Chinese companies is the subject of heated debate in policy circles. For example, the acquisition bid by CNOOC, the Chinese state-owned oil company, to takeover Unocal met with considerable resistance in Washington and was ultimately thwarted. This paper provides a systematic analysis of what happens to U.S. firms when emerging-market acquisitions are successfully completed. Using transaction-specific acquisition data and firm-level accounting data, the goal of this study is to determine how U.S. firms that are acquired by firms from emerging markets fare relative to their non-acquired counterparts.

Evidence from developed-market foreign direct investment (FDI) flows to emerging markets suggests that foreign ownership is associated with improvements in plant productivity (Aitken and Harrision, 1999, Perez-Gonzales, 2005, Arnold and Javorcik, 2005, Petkova, 2007). ${ }^{2}$ The sources of productivity gains are generally attributed to the ability of foreign multinationals to transfer superior technology, bring organizational capital and provide access to international capital markets (Caves, 1996). In the case of recent emerging-market acquisitions, while the role of sovereign wealth funds and the build-up of U.S. dollar reserves in emerging-markets are seen as motivations for acquisitions in developed-markets, the productivity-improving role of technology transfers from emerging- to developedmarkets are not obvious.

Traditional theories of FDI also rely on comparative input costs or market access as the motivating rationale for investment flows from developed to emerging markets. Whereas industrial country acquirers often seek lower labor costs in emerging-markets, emerging-market acquirers may relocate (or insource) manufacturing activity while keeping existing distribution networks in the host country of the acquired business. These differences in motivation for FDI may, in turn, suggest that the post-acquisition performance of target firms will be influenced by the country of origin of the acquiring firm.

\footnotetext{
${ }^{1}$ According to estimates by the International Monetary Fund (IMF), the developing economies as a group had a current account surplus of $\$ 640$ billion in 2007 (IMF, 2007). Because the financial counterpart to this surplus is a deficit on the financial accounts, it represents the net capital outflow to the industrial economies. Just two years earlier, in 2005, net capital flowed in the other direction (the developing economies as a group reported a gross capital inflow of $\$ 720$ billion).

${ }^{2}$ FDI includes "Greenfield” investment in new assets in a foreign country, and acquisition of pre-existing foreign assets (also termed "Brownfield” investment).
} 
The most common motivations for overseas expansions by emerging-market firms include: 1) entering new markets, 2) obtaining natural resources, and 3) acquiring advanced technology and related brand equity. ${ }^{3}$ An example which highlights these factors is Lenovo's 2004 purchase of IBM's personal computer business. This acquisition involved entry into the U.S. market, acquisition of technology, and of an established brand. ${ }^{4}$ Even unsuccessful acquisitions, such as CNOOC's bid for Unocal, point to emerging market demand for natural resources.

The transaction-specific data on cross-border Mergers and Acquisitions (M\&As) used in this paper come from the Thompson Financial SDC Platinum database that records all M\&As involving U.S. firms that were announced between January 1, 1980 and July 1, 2007. We focus on publicly traded U.S. targets both because open financial markets in the U.S. have led to a substantial number of cross-border M\&As, and because public U.S. firms are required to disclose detailed accounting data. It is also worth noting that Forbes (2008) finds evidence that foreigners hold greater shares of their investment portfolios in the United States if they have less developed financial markets, suggesting that our focus on FDI by emerging market firms may provide insights into the implications of broader investment trends into the U.S.

The work that follows complements the existing literature on post-acquisition firm performance. The focus on acquisitions made by emerging country firms allows us to test the general applicability of theories of FDI flows for firms in apparently capital scarce markets.

To evaluate the impact of emerging-country acquisitions on U.S. firm performance we examine both stock market and accounting measures. The stock market measure, abnormal announcement returns, provides a forward-looking estimate of expected shareholder value creation. After the acquisition has taken place accounting measures of profitability, investment, sales and employment allow us to evaluate the ex post performance of U.S. targets.

The first empirical challenge we face in estimating post-acquisition performance is one of causality versus selection. Are emerging-market firms simply picking certain types of acquisition targets or do foreign acquisitions change target-firm performance? There is some evidence in the literature of how acquirers select targets. In particular, the Froot and Stein (1991) model shows that asymmetric information could lead foreign firms to buy U.S. firms in times when the value of the U.S. dollar is low relative to the foreign currency. They provide empirical evidence of a negative relationship between the value of the dollar and FDI flows into the U.S. using aggregate FDI data, and this relationship is also explored in Chen (2008b) using more detailed firm-level data. Harris and Ravenscraft (1990) find

\footnotetext{
${ }^{3}$ See reports by Citigroup (2005) and Boston Consulting Group (2005).

${ }^{4}$ Lenovo had the right to use the IBM brand for five years, but actually dropped it after three years, apparently because its own brand name was already so well established.
} 
evidence that foreign firms prefer technology-intensive industries and Slaughter (2007) describes how U.S. states differ in their incentive packages and taxes with regards to foreign acquirers. ${ }^{5}$ We also find evidence of selection in that emerging country firms tend to acquire public U.S. targets with relatively high levels of sales, employment and total assets.

Crucial to any comparison between pre-and post-acquisition performance of target firms is therefore the issue of selecting an appropriate expected performance benchmark in the absence of the acquisition (Andrade et. al., 2001). The fact is that some firms get acquired while others do not. Ideally, one would like to compare the performance of a firm that receives foreign investment to the performance of the firm's identical twin with no foreign investment. ${ }^{6}$

In this paper we ask the counterfactual question: what would have happened to those firms that did, in fact, receive foreign ownership, if they had not received it? While this exact counterfactual is not typically observable, propensity score matching, which involves selecting a "control” group of nonacquired firms closely matched to the "treatment" group of acquired firms, is one way to artificially create sets of such twins. Propensity score matching can then be combined with difference-in-differences estimates to further eliminate time-invariant and unobservable differences between the acquired and nonacquired firms.

In order to measure the performance of U.S. target firms after they are acquired, we focus on the accounting measure of operating income before depreciation, amortization and taxes (OIBD). In order to control for the relative size of the target firm, we scale OIBD by total assets, thus focusing on return on assets (ROA). We also track changes in other aspects of target firm operations, such as investment, employment, and sales following the acquisition.

We find that the stock price response of target firms is positive and significant around the time of acquisition announcement. Average cumulative returns on the target stock price within a three-day window around the announcement date of the acquisition increase by $8 \%$. This return remains significant and positive when we extend the window to ten and twenty-one business days.

Correspondingly, we find that after acquisition the performance of acquired targets tends to improve. The target firm's return on assets increases by $16 \%$ in the five years following acquisition. Further, there is strong evidence that acquiring firms undertake significant restructuring of target firms. Measures of employment, sales and plant, property and equipment in the target firms decrease in the years after acquisition.

\footnotetext{
${ }^{5}$ At the Federal level there were few legal restrictions on FDI into the United States during the time period studied here, although more stringent laws were recently put into place in order to restrict FDI that threatens U.S. "national security"; these restrictions came into effect in 2007. See: http://www.ustreas.gov/offices/international-affairs/cfius/ ${ }^{6}$ An alternative question, which is explored in Chen (2008a), is whether, given that a firm is acquired, the country of origin of the acquirer matters (so that the control group is other acquired firms rather than non-acquired firms).
} 
The pattern of increasing profitability (income/assets) and declining sales is consistent with improvements in firm-efficiency following acquisition. For instance if firms shut down or get rid of unprofitable divisions, sales would go down but profits as a percent of assets would increase. Also, declining employment and net PP\&E suggest downsizing of divisions to improve overall profitability as a percent of assets. Declining sales in the target firms along with the downsizing of employment are also consistent with the comparative input cost hypothesis where acquirers from emerging-markets may be in the position to exploit the low wages in their home countries by downsizing labor-intensive activities in the foreign country following the acquisition.

The remainder of the paper is structured as follows. Section 2 reviews the existing literature. Section 3 introduces the various datasets employed in the empirical analysis. The details of the differencein-differences propensity score matching estimator are explained in Section 4. Section 5 presents the empirical results and section 6 concludes.

\section{Related Literature}

A large empirical literature compares the productivity of foreign-owned versus domestic-owned firms. Doms and Jensen (1995) find that foreign-owned companies in the U.S. are more productive than domestic-owned ones, but are on average less productive than U.S.-owned multinational companies. A number of studies have investigated the causal link between foreign ownership and plant performance, where the target firm is usually situated in an emerging market while the acquirer firm is from a developed market.

Aitkin and Harrison (1999) conclude from a sample of Venezuelan firms that foreign ownership is correlated with productivity improvements. Using detailed plant-level information from Mexico, PerezGonzales (2005) finds that multinational control leads to large improvements in total factor productivity, particularly in industries that rely on technological innovations from their parent companies. Arnold and Javorcik (2005) use plant-level data from Indonesia and find that foreign ownership leads to significant improvements in productivity in the year of acquisition as well as in subsequent years. Petkova (2008) conducts a similar study using Indian plant level data and concludes that foreign owned plants only experience improvements in productivity at a three-year horizon.

In the developed-market context, a series of papers concentrating on acquisition targets in the United Kingdom, Girma et al. (Girma, 2005; Girma et al., 2006, 2007) document improvements in growth rates of firm performance following foreign acquisitions. These studies, however, do not specifically differentiate between emerging and developed country acquirers. Antkiewicz and Whalley (2006) highlight several case studies of recent completed and failed attempts by Chinese companies to acquire 
firms in the OECD. They suggest that the recent wave of Chinese outbound M\&A is driven by the necessity to acquire access to resources, new technology and distribution networks in the target country.

Our study is also related to studies analyzing the effects of foreign and domestic M\&As on firm stock market performance. Harris and Ravenscraft (1991) examine the effects of inbound U.S. FDI on shareholder wealth over the period 1970-1987 and find that target firm wealth gains are significantly higher in cross-border takeovers than in domestic acquisitions. While they do not focus on the country of origin of the acquiring firms, over their sample period, there were very few emerging-market acquisitions of U.S. firms. ${ }^{7}$

Healy, Palepu and Ruback (1992) analyze the operating performance for the combined firm in domestic acquisitions relative to the industry median and show that the operating cash flows of merged firms actually drop from their pre-merger level on average, but that the non-merging firms in the same industry drop considerably more. Thus, the post-merger combined operating performance improves relative to the industry benchmark. Andrade et. al (2001) use an annual cross sections methodology similar in spirit to Fama and Macbeth (1973) and find that post-merger operating margins (cash flow to sales) improve, on average, relative to industry benchmarks. Using propensity score matching, we find that the return on assets for acquired firms increases significantly relative to the matched control group of non-acquired firms.

\section{Data Description}

Our data sample contains all M\&As involving U.S. firms initiated by firms in emerging markets that are announced between January 1, 1980 and July 1, 2007, and are reported by SDC Platinum, a database from Thompson Financial. The data include all public and private M\&A transactions involving at least $5 \%$ ownership ${ }^{8}$ of a target firm in the U.S ${ }^{9}$. SDC collates information from over 200 English and foreign language news sources, SEC filings and the filings from its international counterparts, trade publications, news wire reports, and proprietary surveys of investment banks, law firms, and other advisory firms. For each transaction, the SDC database provides the date on which the transaction was first announced as well as the date on which the transaction became effective. The database provides characteristics of the target and acquiring firms including: name, nation, industry sector, and primary North American Industry Classification System (NAICS). The database also includes transaction-specific

\footnotetext{
${ }^{7}$ Edwards and Krugman (1995) provide a comprehensive empirical analysis of the growth of inward U.S. FDI from other industrial countries, focusing on economic and national security implications.

${ }^{8}$ The IMF and the OECD define FDI using a 10\% threshold, though a broader definition of FDI is ownership of an amount of shares or voting power that allows participation in the management or control of the target firm.

${ }^{9}$ See Appendix A for a full list of the markets included in the database.
} 
information on percent of shares acquired, the percent of shares owned before and after the transaction is completed, the percent of shares sought by the acquiring firm, and the method of payment.

Over the sample period, SDC covered 7,996 completed M\&A transactions between a foreign acquirer and a U.S. target. Out of that total number, 2,368 M\&A transactions (30\%) were conducted between foreign firms and publicly traded U.S. targets. The focus of the analysis in the paper is on the subsample of 480 outbound M\&A transactions by emerging country firms and U.S. target firms that remain publicly traded after acquisition. Furthermore, we eliminate countries that are tax havens, e.g. Bahamas, Bermudas $^{10}$, etc. which leaves us with a sample of 259 M\&A transactions. Among the remaining deals, 81 transactions involve multiple acquisitions of the same target. We only include the first of multiple acquisitions in our dataset as we are interested in what happens to a U.S. target when it is first acquired by an emerging-market firm. This trims our sample to 214 transactions. Where information is available, these observations cover M\&A transactions that result in a change in majority control in the target firm as well as acquisitions of minority shares. Most of our observations include information on the method of payment, the value of the transaction, and the NAICS codes of the respective acquirer and target firms.

Data on the U.S. target firms come from Compustat and the Center for Research in Securities Prices (CRSP). Compustat reports financial statement data and CRSP contains stock return information. Information provided in SDC on our target firms allows matching across these databases. During this process, we lose observations because some of the target firms are renamed after acquisition or are delisted. The availability of data in Compustat varies significantly by year and by variable. For example, the employment variable is only reported on a voluntary basis in Compustat. Out of the original 214 transactions between emerging country acquirers and public U.S. targets in the SDC dataset, roughly 120 firms (56\%) have performance variables reported in Compustat over the five years post acquisition and 175 firms (81\%) have usable stock returns data in CRSP.

Table 1 presents information by country of origin on the number and value of acquisitions of U.S. firms. The top five emerging market countries whose firms acquired U.S. targets over the period 19802007 are: Hong Kong, Singapore, Mexico, South Korea, and Taiwan. Figure 1 displays the number of publicly traded U.S. firms that were acquired by emerging country firms by year; acquisitions occurred in each of the years in our sample. In about half of all M\&As reported in SDC information is available on the value of the deal. Figure 2 presents this information together with the number of deals and the industry in which the target firm is located. In the figure the surface area of each bubble shows the total value of deals within each one-digit industry sector, while the location of the bubble is determined by the average value and the total number of deals within an industrial sector. The figure indicates that in about

${ }^{10}$ See Appendix A for a list of tax-haven markets as defined by the OECD (2008). 
half of all transactions the target firm is in the manufacturing sector and the average value of acquisitions in the manufacturing sector is much larger than the value of acquisitions in other industries.

Table 2 displays the top 20 deals by acquisition value between emerging country firms and public U.S. targets. About half of the top twenty M\&A transactions are horizontal, meaning that the acquirer and the target are in the same industry. In our full sample about one sixth of the deals involve horizontal M\&As and about one third of the deals involve an acquisition of 50 percent or more of the target. Finally, Table 3 provides average accounting information (OIBD, sales and employment) for the target firms sorted by NAICS industry.

\section{Empirical Strategy}

\subsection{Difference-in-Differences Matching Estimation}

It seems unlikely that emerging country firms acquire U.S. firms at random. As discussed in the introduction, ideally, in order to evaluate the impact of foreign ownership we would like to have information on the set of prospective firms from which the target was selected. In other words, we would like to compare the performance of a firm that receives foreign investment to the performance of the firm's identical twin (or multiple) with no foreign investment. While this sort of counterfactual is not generally observable, we use propensity score matching techniques to construct a control group of nonacquired U.S. firms that closely match the U.S. targets. A firm is "selected" into the control group if it is sufficiently similar to acquired U.S. firms on the basis of the key determinants of the acquisition decision. In other words, our goal is to find a set of control firms that are a priori equally likely to be acquired by an emerging-market firm as those firms which ultimately are acquired.

Let $A_{i, t} \in\{0,1\}$ be a dummy variable indicating whether a U.S. firm is acquired by an emergingmarket firm at time $t$ and let $y_{i, t+u}^{1}$ denote target firm performance $u$ periods after the acquisition takes place, where $u \geq 0$. The performance of a matched non-acquired U.S. firm is given by $y_{i, t+u}^{0}$. For a given U.S. firm, we will only observe performance in one of the two states; foreign acquisition $\left(y_{i, t+u}^{1}\right)$, or not $\left(y_{i, t+u}^{0}\right)$. The average effect of an emerging-market firm acquisition of a U.S. target is the following:

$$
\begin{aligned}
& E\left[y_{i, t+u}^{1}-y_{i, t+u}^{0} \mid A=1\right] \\
& =E\left[y_{i, t+u}^{1} \mid A=1\right]-E\left[y_{i, t+u}^{0} \mid A=0\right]-\left\{E\left[y_{i, t+u}^{0} \mid A=1\right]-E\left[y_{i, t+u}^{0} \mid A=0\right]\right\}
\end{aligned}
$$

The term in the first line is the average treatment effect on the treated (ATET), and the term in the second line in braces is a "selection" term, which is zero if the assignment to the treatment and control groups is random. Our assumption is that firms have observable characteristics, $\mathbf{X}$, that make them 
attractive targets. Our approach is to match acquired and non-acquired firms on the basis of these Xs and then calculate the treatment differential (the effect of being acquired) on each of the outcome variables of interest. The average of the differential over all acquired firms and all $\mathbf{X s}$ measures the average effect of foreign acquisition. Formally, Angrist and Krueger (2000) show that effect of the treatment on the treated is given by

$$
\begin{aligned}
& E\left[y_{i, t+u}^{1}-y_{i, t+u}^{0} \mid A=1\right]=E\left\{E\left[y_{i, t+u}^{1} \mid X, A=1\right]-E\left[y_{i, t+u}^{0} \mid X, A=0\right] \mid A=1\right\} \\
& =E\left[\Delta_{x} \mid A=1\right],
\end{aligned}
$$

where $\Delta_{x}=E\left[y_{i, t+u}^{1} \mid X, A=1\right]-E\left[y_{i, t+u}^{0} \mid X, A=0\right]$. The underlying assumption is that all the firms (whether acquired or not) have the same expected performance under domestic ownership. This is referred to as the conditional independence assumption (CIA):

$$
E\left[y_{i, t+u}^{0} \mid X, A=1\right]=E\left[y_{i, t+u}^{0} \mid X, A=0\right]=E\left[y_{i, t+u}^{0} \mid X\right]
$$

For the CIA to be satisfied, the vector $\mathbf{X}$ should contain all variables that affect both acquisition and performance outcomes. The choice of variables included in $\mathbf{X}$ is described in more detail below. Another assumption required for matching is that it is not possible to predict the probability of a foreign acquisition perfectly, i.e. $0<\operatorname{Pr}(A=1 \mid X)<1$.

Matching on a vector of variables is difficult since it requires weighting differences in one dimension against another. Rosenbaum and Rubin (1983) provide a solution to this dimensionality problem by matching firms on propensity scores, which in our context is the conditional probability of being acquired by an emerging county firm given $\mathbf{X}$ :

$$
P_{i}=\operatorname{Pr}\left(A_{i, t}=A\left(X_{i, t-1}\right)\right) .
$$

This matching technique allows us to take into account differences in observable characteristics across the firms in our database. We then combine matching with difference-in-differences analysis to eliminate the differences between the acquired and control firms that are unobservable and time invariant.

Rather than treating each of our firms linearly and with the same weight, our difference-indifferences estimator paired with propensity score matching allows us to include only acquired firms within the common support and picks control firms according to the metric function specific to the matching method. We limit the common support to only contain those treated firms that do not lie above the maximum or below the minimum propensity score for the matched control group. Similarly, matched control group firms that lie above the maximum or below the minimum propensity score for the treated firms are also dropped from the analysis. 
In our analysis, we use the Mahanalobis distance metric, which allows us to confine the matching between the acquired and control firms to the same 2-digit industry. Mahanalobis metric matching by itself uses the observable covariates directly, by minimizing a distance defined for covariate values $\mathrm{X}_{1 \text { (treated) }}$ and $\mathrm{X}_{2 \text { (control) }}$ as

$$
\left\{\left(X_{1}-X_{2}\right)^{T} S_{c}^{-1}\left(X_{1}-X_{2}\right)\right\}^{1 / 2},
$$

where $S_{c}$ is the control sample covariance matrix. For the combined method, all non-acquired U.S. firms within intervals surrounding each acquired firm's propensity score are identified as potential matches, and then Mahalanobis metric matching is applied to the subset of covariates, in our case 2-digit industry characteristics, to make final selections from these potential matches. Finally, the standard errors from the matching estimation are bootstrapped as suggested by Becker and Ichino (2002).

\subsection{Evidence of Selection}

In order to examine whether our assumption that firms are not randomly selected for acquisition is justified we check whether firm characteristics prior to acquisition are correlated with subsequent foreign ownership. Our test involves a regression of our various performance measures on two dummy variables. The first dummy variable indicates those U.S. firms with foreign ownership in year $t$. The second dummy variable is switched on three years prior to the ownership change, for those U.S. firms that were eventually foreign acquisition targets. We also control for industry, region and year fixed effects in the regression. The estimation results, presented in Table 4, illustrate that future foreign acquisition targets are larger in size, measured by log sales and log total assets, than non-acquired domestic firms up to three years before acquisition. Furthermore, the regression estimates indicate that acquired firms have more employees and higher debt than non-acquired firms. These systematic differences indicate that foreign investors do not choose target firms at random. Our analysis of the post acquisition performance of U.S. firms takes this selection into account.

\subsection{Timing Issues}

Unlike longitudinal matching studies, where treatment occurs uniformly at one point in time, the firms in our data set are targets of acquisition at varying times. This variation in treatment timing poses the challenge of how to assign counterfactual treatment dates to the firms that are not acquired by emerging-market firms. We follow Petkova's (2008) approach of proportional-random acquisition time assignment. We determine the fraction of the total number of acquisitions that occur in each calendar year during our sample period, and then assign the hypothetical treatment year to the firms in the control group in the same proportion as their occurrences in the acquisition group. For example, if one tenth of all acquisitions occurred in 1995 in our sample of targets, then one tenth of all firms in the control group 
receive the hypothetical treatment year 1995. Before assigning the date, we make sure that the control firm's year of incorporation precedes the treatment year and that the firm remains non-acquired throughout the entire span of our data.

\subsection{Propensity Score Matching Estimation}

After assigning the hypothetical foreign acquisition dates to the control firms that are not acquired (do not receive treatment) over our sample period, we need to realign the time series data for each firm. More specifically, in the year of acquisition (actual or hypothetical), we set $t=0$, in the year following the acquisition $\mathrm{t}=1$, and in the year prior to the acquisition, $\mathrm{t}=-1$, etc. The propensity score is the estimated probability of being acquired in period $t=0$ based on firm characteristics in period $t=-1$. We estimate this probability using a probit model, where the dummy variable $A_{i, t}$ equals 1 in the year a firm is the actual target of acquisition and zero otherwise ${ }^{11}$.

\subsubsection{Choice of Covariates}

We select our control group of non-acquired firms based on a set of observable characteristics that comprise the vector $\mathbf{X}$. The control variables include factors that drive both the acquisition and performance of the firm, such as: age, size (measured by log of total assets, log of sales and log of employment), operating income, debt, cash, net income, and net property, plant, and equipment. In the estimation, the values of each of these variables are from the year prior to the actual or hypothetical acquisition year. ${ }^{12}$ The "age" of a firm indicates the level of development of a potential target. Variables such as total assets and sales convey information about the market power of the target firm as well as its productive capacity. Operating income before depreciation (OIBD) and net income describe the profitability of the target firm. Debt and cash variables are indicators of the internal structure of the firm. Measures of property, plant and equipment gauge the physical capital stock of a firm. Lastly, we include year, region and industry dummies in the vector of control variables, where industry dummies are based on 2-digit NAIC codes and regional dummies are based on the U.S. state where the target firm is located.

\footnotetext{
${ }^{11}$ Alternatively, we could also assign zero to a target firm where there has been an acquisition announcement that eventually fell through. Due to the limited amount of data, however, this analysis was not feasible.

${ }^{12}$ In choosing the year preceding the acquisition, there arises a concern of an "Ashenfelter Dip.” This term is based on the finding in Ashenfelter (1978) that in job program evaluations, participants tend to experience a temporary decline in earnings prior to enrolling in a program. In this data set of target firms, however, there is no visible decline in target firm performance in the year prior to acquisition. As a robustness check we also use variables in different years prior to acquisition, the results remain unchanged.
} 


\section{Results}

\subsection{Preliminary Evidence: Stock Market Reaction to Acquisition Announcements}

If capital markets are semi-strong form efficient with respect to public information, stock prices will quickly adjust following an acquisition announcement, incorporating any expected value changes (Andrade et al, 2001). The two commonly used event windows are the three days immediately surrounding the acquisition announcement, and a longer window beginning several days prior to the announcement and ending at the close of the acquisition. We examine the abnormal stock return for the acquired targets around various different windows of time surrounding the announcement of the acquisition.

We calculate the mean cumulative return of the target stock price within a one, three, and twenty day window of the announcement date. We assume that stock prices follow a single factor market model. Our estimation period is 280 days before and up until 30 days preceding the event date. Using a standardized value of the cumulative abnormal return, we test the null hypothesis that the return is equal to zero. ${ }^{13}$

Table 5 displays announcement period abnormal returns for U.S. targets that are acquired by emerging country firms. The announcement period cumulative abnormal return over the three-day window is $8.9 \%$ for 175 completed acquisitions. When the event window is expanded to three days prior to the acquisition announcement and ending three days after the announcement, the mean abnormal return is essentially identical. Over an even longer window of twenty days, the mean abnormal return increases to $9.7 \%$. In comparison to domestic U.S. M\&As, where target firms' average three-day abnormal return is around $16 \%$ for the three-day window and rises to $24 \%$ over the longer event window of 20 days (Andrade et al. (2001)), acquisitions of U.S. targets by emerging-country firms tend to have lower abnormal returns.

\subsection{Propensity Score Matching Estimates}

Our approach to constructing an appropriate comparison group of non-acquired firms involves a two-step matching process. The first step, a probit regression, estimates the probability of foreign acquisition based on past values of various measures of firm performance (age, OIBD, cash, sales, assets, employment, debt, income) as well as state, year and industry fixed effects. The results of the probit indicate that firms with more cash, and those firms located in certain states and from specific industries are more likely to be acquired. We impose a common support by dropping treatment observations (firms that are acquired) whose propensity score is higher than the maximum or less than the minimum

\footnotetext{
${ }^{13}$ In future work we plan to also compare target firm returns to both their matched control firm returns and their industry average return on the announcement date.
} 
propensity score of the firms that are not acquired. The second step involves using the Mahalanobis distance metric to select firms for the control group that are within the same 2-digit industry as the acquired firms.

Figure 3 provides an illustration of the effects of our two-step Mahalanobis matching approach. The three densities plotted in the figure depict the predicted probability, i.e. propensity score, of acquisition for the acquired firms (red), the non-matched and non-acquired firms (blue), and the Mahalanobis metric matched non-acquired firms (green). The Mahanalobis matching estimator performs extremely well as evidenced by the proximity between the density of the acquired firms and that of the Mahanalobis matched non-acquired firms. ${ }^{14}$ In terms of our two step process, if we did not "select" our control group, this group would include all U.S. firms that are not acquired (the blue line). Our two-step matching involves constructing an appropriate counterfactual for each acquired firm given the set of observable covariates available for the firms. The propensity score provides a summary index of all the covariates combined, so that matching essentially brings the group of control firms closer to the acquired firms on all available dimensions.

The density plot in Figure 3 reveals that among the non-acquired firms a large proportion have almost zero probability of being acquired. A simple difference-in-difference estimator would treat these firms the same as those non-acquired firms that are more likely to be acquired. The Mahanalobis matching estimator, in contrast, only selects firms that are similar to the acquired firms both in terms of propensity score as well as in industry. In other words, propensity score matching in this context ensures that our comparisons involve firms that are very similar prior to acquisition. One could argue that this approach biases against finding differences in post acquisition performance (given that the firms are so similar prior to acquisition), but it also ensures that our tests will not simply be picking up differences in acquired and non-acquired firm performance that are unrelated to acquisition.

\subsubsection{Balancing Test}

One way to assess the performance of our propensity score matching is to calculate the standardized differences for the covariates in our probit regression. Specifically, for each covariate, we take the average difference between the acquired firms and the matched control firms and normalize it by the pooled standard deviation of the covariate in the acquired and control group samples. Based on Rosenbaum and Rubin (1985), we calculate the following measure:

\footnotetext{
${ }^{14}$ We also try alternative matching estimators, such as kernel matching and propensity score reweighting. The difficulty with kernel matching is the selection of an appropriate bandwidth parameter. Although the point estimates based on propensity score reweighting are similar to our Mahalanobis results, the properties of the standard errors from propensity score reweighting are less clear.
} 


$$
\operatorname{SDiff}\left(X_{k}\right)=100 \frac{\frac{1}{n_{1}} \sum_{i \in\left\{A_{i}=1\right\}}\left[X_{k i}-\sum_{j \in\left\{A_{j}=0\right\}} W\left(P_{i}, P_{j}\right) X_{k j}\right]}{\sqrt{\frac{\operatorname{var}_{i \in\left\{A_{i}=1\right\}}\left(X_{k i}\right)+\operatorname{var}_{j \in\left\{A_{j}=0\right\}}\left(X_{k j}\right)}{2}}},
$$

where $\mathrm{n}_{1}$ is the number of acquired firms and $\mathrm{n}_{0}$ is the number of non-acquired firms in the control group.

Table 6 shows that our propensity score method does a good job of matching a set of control group firms that were not acquired to the set of firms that were acquired by emerging-market firms along the dimensions of the observable covariates. The balancing test results indicate that the differences in our matched parameters are all well below $20^{15}$ indicating that our approach is capable of grouping together relatively similar firms. In particular, the covariates log cash, log sales, log employment, and log of net property, plant and equipment before matching show significant differences in means between acquired and non-acquired firms. After matching, however, the means of the covariates between the two groups are not significantly different.

For instance, consider the firm-size characteristic as measured by log sales. The first row of coefficients for log sales compares the acquired (treated) firms with the non-acquired (control, unmatched) firms. In other words, the "unmatched control" refers to the set of firms that would have otherwise comprised the control group had we not undertaken propensity score matching. The coefficients for log sales in the first row suggest that the acquired firms are significantly larger, on average, than the unmatched set of control firms. The difference in size is statistically significant as evidenced by the tstatistic and p-values in the final two columns. The second row presents mean log sales numbers for the acquired firms along with the "matched control" firms that were not acquired. In stark contrast, the differences in log size are not significantly different across the treated and control groups when matching takes place. In fact the reduction in bias as a result of propensity score matching along the dimension of $\log$ sales is about $83 \%$. The reduction in bias for other observable covariates ranges from $20 \%$ for the firm-age variable to $96 \%$ for the firm-cash variable.

\subsection{Post-Acquisition Performance}

Tables 7, Panels A-D present our difference-in-differences Mahalanobis matching results for various measures of post-acquisition firm-performance. $t=\{0,5\}$ denotes the post-acquisition year. The second column presents the matched coefficient estimate. Estimates in bold indicate statistical differences in measured post-acquisition performance for acquired and matched non-acquired firms.

\footnotetext{
${ }^{15}$ A value for the standardized difference between treated and matched control mean values suggested by Rosenbaum and Rubin (1983).
} 
Common support refers to the set of firms for whom the propensity score range overlaps across control (non-acquired) and treated (acquired) firms. Off support refers to the number of treated (acquired) firms whose propensity score lay above the maximum value or below the minimum value for the control (nonacquired) firms. Note that changes in post-acquisition performance are calculated relative to year $\mathrm{t}=-1$, prior to the acquisition.

Panel A presents results for OIBD scaled by total assets, also referred to as return on assets (ROA). These estimates indicate that the ROA for acquired firms declines significantly compared to the firms in the "propensity score matched" control sample in the year of acquisition. It appears that profits continue to decline in years 1-3 following the acquisition but the decline is not statistically significant. In years four and five after the acquisitions the ROA increases significantly for acquired firms (relative to the non-acquired firms in our control group). In particular, the ROA increases by $8.3 \%$ in year four and $7.8 \%$ in year five for the acquired firms relative to the control sample and also relative to the year prior to the acquisition. The time-series pattern in the ROA numbers is consistent with restructuring in the early years following the acquisition leading to improved profitability in later years. We also conducted an Ftest of joint significance that shows that the post-acquisition increase in profitability is jointly significant across the five years following the acquisition.

The advantage of our methodology is that we are able to identify the timing of the profitability improvements. Propensity score matching also requires large samples with substantial overlap between groups of the treated (acquired) and control (matched non-acquired) firms. From Table 7a, we see that the sample size of control firms under "common support" are an order of magnitude higher than the treated group suggesting that our estimates are measured with high precision. Moreover, the numbers under "offsupport" suggest that there is substantial over lap in the treated and control samples since only two firm years of treated observations are excluded from the estimation. A caveat that remains is that while propensity score matching attempts to identify matched twins in the control group and difference-indifferences estimation accounts for time-invariant, unobservable differences across treated and matched firms, hidden bias may remain because matching only controls for observed variables to the extent that they are perfectly measured (Shadish, Cook and Campbell, 2002). Also, to the extent that there are unobservable time-varying differences in firm characteristics across the treated and control samples, we are unable to account for them. However, it is not clear what unobservable and yet time-varying firm characteristics could vary across the two samples of firms.

The results in Panels B-D in Table 7 indicate that employment, net property, plant, and equipment (PP\&E), and sales all decrease significantly for acquired firms (again, relative to matched control nonacquired firms) in the year of and the five years after the acquisition. While the decline in employment 
and net PP\&E is significant only in the early years, the decline in sales appears to persist across the five years following the acquisition.

The pattern of increasing profitability (income/assets) and declining sales is consistent with improvements in firm-efficiency following acquisition. For instance if firms shut down or get rid of unprofitable divisions, sales would go down but profits as a percent of assets would increase. Also, declining employment and net PP\&E suggest downsizing of divisions to improve overall profitability as a percent of assets.

The results of increasing profitability are also consistent with the hypothesis that foreign ownership is associated with improvements in plant productivity (Aitken and Harrision, 1999, PerezGonzales, 2005, Arnold and Javorcik, 2005, Petkova, 2007). Declining sales in the target firms along with the downsizing of employment are also consistent with the comparative input cost hypothesis. Acquirers from emerging-markets come from environments where labor costs are low and they may be in the position to "insource" jobs by exploiting the low wages in their home countries by downsizing laborintensive activities in the foreign country following the acquisition. However, the U.S. target also experiences improvements in profitability with more streamlined but efficient operations following restructuring by the emerging-market acquirer.

\subsection{Simple Difference-in Differences Estimation}

To highlight the importance of constructing an appropriate benchmark for comparison to evaluate post-acquisition performance we conduct a simple difference-in-differences estimation without propensity score matching. Here the underlying assumption is that US targets are chosen at random by emergingmarket acquirers. Table 8 (Panels A-D) present the results. From the coefficient estimates we may erroneously conclude that there is no significant difference in the post-acquisition performance between the treated (acquired) and control (non-matched non-acquired) firms. The estimates suggest that OIBD/assets, employment, net PP\&E and sales are not significantly different across the two groups of firms following the acquisition. The simple difference-in-differences are essentially comparing the postacquisition performance of targets to the performance of all non-acquired U.S. firms. If the acquired firms are bigger on average (as indicated in Table 4) in terms of assets, sales and employment before the acquisition, and continue to be statistically different along these dimensions after the acquisition in comparison to the sample of all non-acquired firms, simple difference-in-differences estimates would lead to the inference that emerging-market acquisitions do not significantly alter the performance or operations of the target firms. ${ }^{16}$ However, a comparison of the target firms with a set of hypothetical twin firms in the

\footnotetext{
${ }^{16}$ In unreported results we find that the observable characteristics (such as size and employment) that distinguish the acquired and full (unmatched) set of non-acquired firms do not change significantly three years post-acquisition.
} 
matched control set suggest that emerging-market acquirers undertake significant restructuring of the target firms following the acquisition. The post-performance indicators from Section 5.3 show that the acquirers downsize unprofitable divisions, as evidenced by falling sales and employment concomitant with a significant increase in overall firm-profitability. This simple example serves to illustrate the importance of constructing a careful benchmark from which to evaluate post-acquisition performance and the advantage of propensity score matching in this context.

\subsection{Robustness Checks}

SDC Platinum also provides information about acquisitions that are announced but not completed or withdrawn. Using this sample of failed transactions we can examine whether the firms that were potential acquisition targets differ from their non-acquired counterparts. If it is foreign ownership that drives the post-acquisition performance of the acquired firms, then we expect that following propensity score matching, the firms that were "potential" targets should perform similarly to the firms that are in the matched control sample but not the subject of foreign interest since the foreign acquisition was never successfully completed. Although it is not possible to test this hypothesis given the limited number of failed acquisitions, Table 9 provides suggestive evidence; the eighteen potential targets in our sample experience declines in employment and increases in sales in the year the M\&A transaction is announced and are similar to a group of matched non-acquired firms in the years after the failed acquisitions, suggesting that post-acquisition performance of acquired firms is driven by the transfer of ownership to foreign hands. However, given the small number of failed acquisitions in our sample, more formal statistical analysis is not possible.

We also perform a number of additional robustness checks that involve dividing our sample of acquired firms into various subgroups consisting of: 1) majority and minority control acquisitions, 2) acquisitions financed solely by cash, 3) only manufacturing firms, 4) acquiring firms located in Hong Kong, Singapore, Taiwan and South Korea, and lastly, 5) firms not in the same industry as the acquiring firm. The estimates are shown in Table 10 (Panels A-H). The statistical significance of the results varies due to sample sizes. For example, for the group of horizontal acquisitions, in which both acquiring and target firms share the same industry, the sample size is much smaller than that for diversifying acquisitions. Thus, although the magnitudes of the estimates are similar to those of the whole sample, the statistical significance is not. Overall, the robustness checks confirm the results in the main analysis when using the full sample. 


\section{Conclusion}

This paper undertakes the first systematic analysis of the performance of U.S. firms that are acquired by firms located in emerging markets. To do so, we examine both stock market and accounting based measures of firm performance following the announcement of an acquisition of a U.S. firm by an emerging-market firm. In particular, we use transaction-level M\&A information along with firm-level financial statement data to examine the post-acquisition performance of publicly listed U.S. targets.

Our results suggest that emerging country firms tend to acquire public U.S. targets with relatively high levels of sales, employment and total assets. The selection of acquisition target is therefore nonrandom. To address the issue of selection, we employ propensity score matching to carefully construct a matched sample of control firms that were not acquired. The matching methodology is combined with difference-in-differences estimation to eliminate time-invariant unobservable firm characteristics.

The stock price response of these U.S. targets is positive and significant around the time of the acquisition announcement. Following the acquisition, the performance of target firms tends to improve. In particular, the return on assets in target firms increases by 16\%, on average, in the five years following the acquisition. The evidence also suggests that U.S. target firms undergo significant restructuring after acquisition by an emerging-market firm. In particular, employment and capital decrease, suggesting that divisions may be sold off or closed down. This conjecture is also supported by the fact that sales also decline after acquisition.

Our results indicate that (i) acquisitions by firms from emerging markets influence postacquisition performance of target firms (sales and employment decline, profits rise); and (ii) there is selection along observable characteristics based upon which emerging market firms choose acquisition targets in the U.S. (higher sales, assets, employment). In the paper we attempt to control for (ii) using propensity-score-matching and difference-in-difference estimation. There remains the possibility that selection based on time-variant unobservable characteristics (that are orthogonal to the observable characteristics used in our propensity score matching) may be driving our results. However, the evidence presented in the paper strongly indicates that emerging market firm acquisitions impact the performance of U.S. target firms. More generally, the results in the paper serve to illustrate the importance of constructing careful benchmarks from which to evaluate post-acquisition performance and the advantage of propensity score matching in this context. 


\section{References}

Aitken, Brian J. and Ann E. Harrison, 1999. Do Domestic Firms Benefit from Direct Foreign Investment? Evidence from Venezuela. American Economic Review, Vol. 89, 605-618.

Andrade, G., Mitchell, M., and Stafford E., 2001. New Evidence and Perspectives on Mergers. The Journal of Economic Perspectives, Vol. 15, No. 2, 103-120.

Angrist, J. D. and Krueger, A. B. 2000. Empirical Strategies in Labor Economics, in A. Ashenfelter and D. Card eds. Handbook of Labor Economics, vol. 3. Sections 1 and 2.

Antkiewicz, A. and Whalley, J., 2006. Recent Chinese Buyout Activity and the Implications for Global Architecture. NBER Working Paper No. W12072.

Arnold, J. M. and Javorcik, B. S. 2005. Gifted Kids or Pushy Parents? Foreign Acquisitions and Plant Performance in Indonesia. Development Studies Working Paper No. 197. Centro Studi Luca D’Agliano, March.

Ashenfelter, O. 1978. Estimating the Effect of Training Programs on Earnings. Review of Economics and Statistics 60, 1, 47-57.

Becker, S. and Ichino, A. 2002. Estimation of average treatment effects based on propensity scores. The Stata Journal, Vol.2(4), 358-377

Chari, A., Ouimet, P. and Tesar, L. 2007. The Value of Control in Emerging Markets, mimeo.

Chen, Wenjie 2008a. Does the Country of Origin of the Acquiring Firm Impact Performance? mimeo. http://www-personal.umich.edu/ wenjiec/jobmarket/wenjiec job market_paper.pdf

Chen, Wenjie 2008b. The Relationship between Exchange Rates and FDI, mimeo.

Citigroup, 2005. Cross-Border Acquisitions: A Value Creation Strategy for Emerging Market Multinational Companies.

Dehejia, R. H., And Wahba, S. 2002. Propensity score matching methods for non-experimental causal studies. Review of Economics and Statistics 84, 1, 151-161.

Doms, M. E. and Jensen, J.N., 1995. Geography and Ownership as Bases for Economics Accounting. The University of Chicago Press, Ch. Comparing wages, skills, and productivity between domestically and foreign-owned manufacturing establishments in the United States, pp. 235-258.

Fama, E. and MacBeth, J., 1973. Risk, Return, and Equilibrium: Empirical Tests. Journal of Political Economy, 81:3, 607

Forbes, Kristin, 2008. Why Do Foreigners Invest in the United States? NBER Working paper \#13908.

Froot, K, and Stein, J., 1991. Exchange Rates and Foreign Direct Investment: An Imperfect Capital Markets Approach. Quarterly Journal of Economics, 106:4, pp. 1191-1217.

Girma, S., 2005. Technology transfer from acquisition FDI and the absortive capacity of domestic firms: An empirical investigation. Open Economics Review 16, 175-187. 
Girma, S. and Goerg, H., 2007. Evaluating foreign ownership wage premium using a difference-indifferences matching approach. Journal of International Economics 72, 97-112.

Girma, S., Kneller, R., and Oisu, M., 2007. Do exporters have anything to learn from foreign multinationals? European Economics Review 51, 981-998.

Graham, E. and Krugman, P., 1995. Foreign Direct Investment in the United States, 3rd Edition, Institute for International Economics, Washington, D.C.

Harris, R. and Ravenscraft, D., 1990. The Role of Acquisitions in Foreign Direct Investment: Evidence from the U.S. Stock Market. The Journal of Finance, Vol. 46, No. 3, 825-844.

Haskel, J., Pereira, S., and Slaughter, M. 2007. Does Inward Foreign Direct Investment Boost the Productivity of Domestic Firms? Review of Economics and Statistics 89(3), 482-496.

Healy, P.M., Palepu, K.G. and Ruback, R.S., 1992. Does corporate performance improve after mergers? Journal of Financial Economics 31, 135-175.

International Monetary Fund (2007). World Economic Outlook. Washington: IMF, April, http://www.imf.org/external/pubs/ft/weo/2007/01/data/index.aspx

OECD (2008), Tax Cooperation: Toward a Level Playing Field, http://www.oecd.org/document/55/0,3343,en_2649_33745_41233143_1_1_1_37427,00.html

Perez-Gonzales, Francisco, 2004. The Impact of Acquiring Control on Productivity: Evidence from Mexican Manufacturing Plants, mimeo.

Petkova, N. 2008, Does Foreign Ownership Lead to Higher Firm Productivity? mimeo.

Rosenbaum, P. and Rubin, D., 1983. The central role of the propensity score in observational studies for causal effects. Biometrika 70, 41-55.

Rosenbaum, P. and Rubin, D., 1985. Constructing a control group using multivariate matched sampling methods that incorporate the propensity score. The American Statistician 39, 1, 33-38.

Shadish, W.R., T.D. Cook and D.T. Campbell (2002). Experimental and quasi-experimental designs for Generalized Causal Inference. Houghton-Mifflin, Boston:MA.

Wells, L., 1983. Third World Multinationals: The Rise of Foreign Investment from Emerging Markets, The MIT Press, Cabridge:MA. 


\section{Appendix A}

Acquiring Countries in the sample:

Algeria, Argentina, Bahrain, Brazil, China, Costa Rica, Croatia, Ecuador, Egypt, Hong Kong, India, Indonesia, Kuwait, Malaysia, Mexico, Nigeria, Papua N Guinea, Russian Fed, Saudi Arabia, Singapore, South Africa, South Korea, Taiwan, Thailand, Trinidad \& Tobago, Uganda, Uzbekistan, Venezuela

Tax Haven Countries (as defined by the OECD, 2008) excluded from the sample:

Bahamas, Bermuda, British Virgin Islands, Cayman Islands, Cyprus, Netherland Antilles, Panama

\section{Appendix B}

Steps followed in our propensity score matching methodology:

1. Run Probit regression where:

(a) Dependent variable: $Y=1$, if a firm is acquired by an emerging-market firm; $Y=0$, otherwise.

(b) Choose appropriate conditioning variables, covariates which are observable firm characteristics such as age, size, profitability, financing-mix, etc.

(c) Obtain propensity score: predicted probability (p) or $\log [\mathrm{p} /(1-\mathrm{p})]$.

2. Match each acquired firm to one or more non-acquired firms based on propensity score. We use Mahalanobis metric matching in conjunction with propensity score matching to choose one nonacquired firm from multiple matches restricted to be within the same two-digit industry as the acquired firm. Procedure:

(a) Calculate the distance between the acquired firm and all non-acquired firms in the same industry. The distance, $\mathrm{d}(\mathrm{i}, \mathrm{j})$ can be defined by the Mahalanobis distance:

$\mathrm{d}(\mathrm{i}, \mathrm{j})=\left\{\left(X_{1}-X_{2}\right)^{T} S_{c}^{-1}\left(X_{1}-X_{2}\right)\right\}^{1 / 2}$

where $X_{1}$ and $X_{2}$ are propensity scores for acquired firm i and non-acquired firm j, and $\mathrm{S}_{\mathrm{c}}$ is the sample covariance matrix of the matching variables from the full set of control group firms.

(b) The non-acquired firm, $\mathrm{j}$, with the minimum distance $d(\mathrm{i}, \mathrm{j})$ is chosen as the match for acquired firm i, and both are removed from the pool.

(c) Repeat the above process until matches are found for all acquired firms.

(d) The standard errors from the matching estimation are bootstrapped following Becker and Ichino (2002).

3. Run multivariate difference-in-difference regression to eliminate time-invariant, unobservable differences between acquired (treated) and non-acquired (matched control) firms to examine post acquisition firm performance. 


\section{Appendix C}

Details of Sample Construction:

\begin{tabular}{|c|c|c|}
\hline & $\mathrm{N}$ & Percent \\
\hline $\begin{array}{l}\text { Number of Transactions with a Foreign } \\
\text { Acquirer and US Target }\end{array}$ & 7,996 & \\
\hline $\begin{array}{l}\text { Number of transactions with a Foreign } \\
\text { Acquirer and a Public US Target }\end{array}$ & 2,368 & $29.60 \%$ \\
\hline $\begin{array}{l}\text { Number of Completed } \\
\text { Transactions with Emerging- } \\
\text { Market Acquirer and public US } \\
\text { Target }\end{array}$ & 480 & $20 \%$ \\
\hline $\begin{array}{l}\text { Number of Transactions with } \\
\text { Tax Haven Country }{ }^{17} \text { as } \\
\text { domicile of Acquirer }\end{array}$ & 221 & $46 \%$ \\
\hline $\begin{array}{l}\text { Number of Firms with Multiple } \\
\text { Acquisitions }\end{array}$ & 45 & $17 \%$ \\
\hline
\end{tabular}

Source: SDC Thompson M\&A database.

${ }^{17}$ Countries are listed in Appendix A. 
Figure 1: Emerging-Market Firm Acquisitions of U.S. Targets by Year

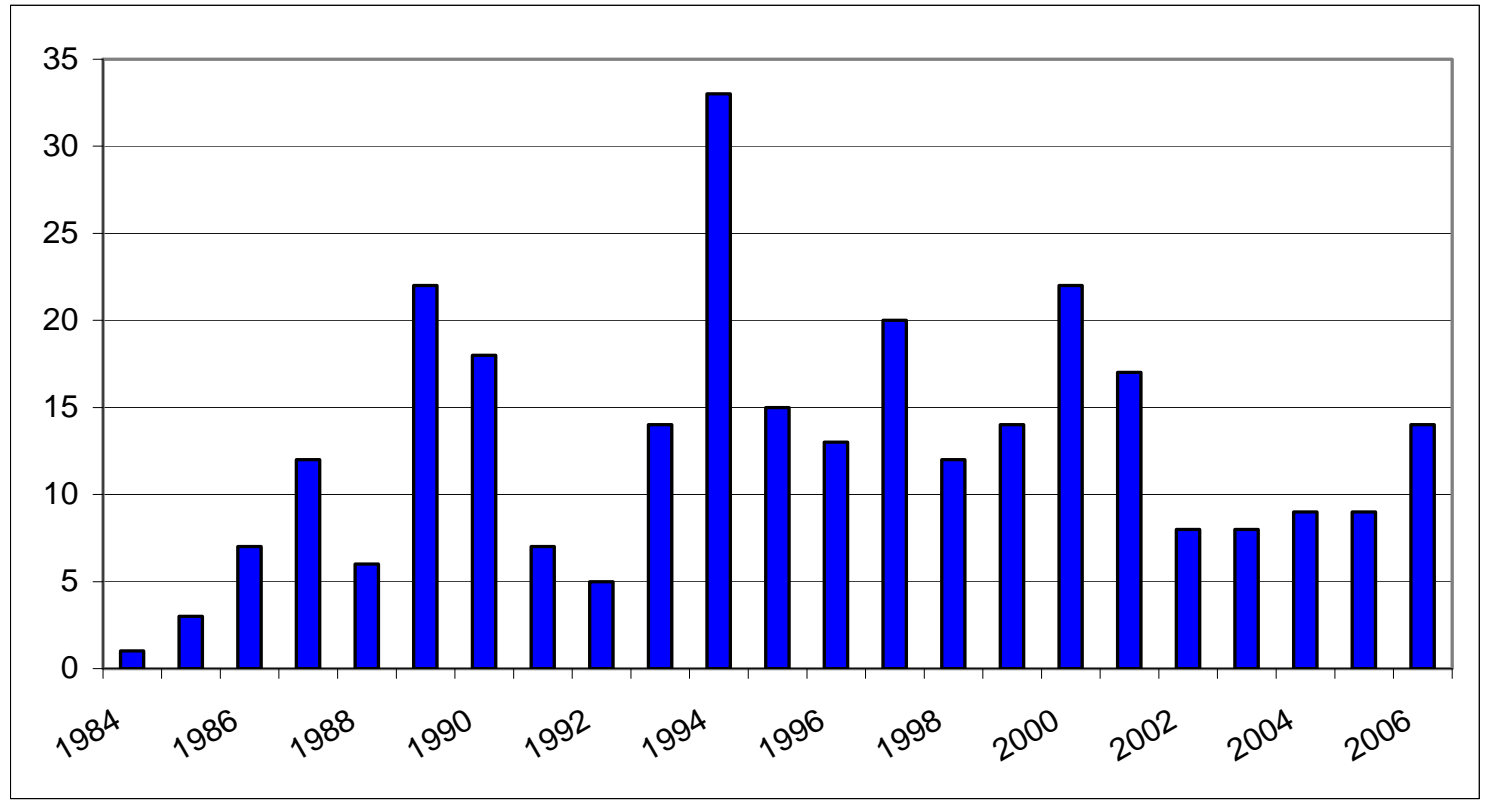

Source: SDC Thomson M\&A database. This figure shows the number of acquisitions of U.S. firms by emerging-market firms in each year of our sample 1980-2007. 
Figure 2: Number and Value of M\&A deals by Target Sector

Notes: The figure presents information on the industries in which the target firms belong along with the number (horizontal axis) and average value of the transaction (vertical axis). The surface area of each bubble shows the total value of deals within each one-digit industry sector, while the location of the bubble is determined by the average value and the total number of deals within an industrial sector.

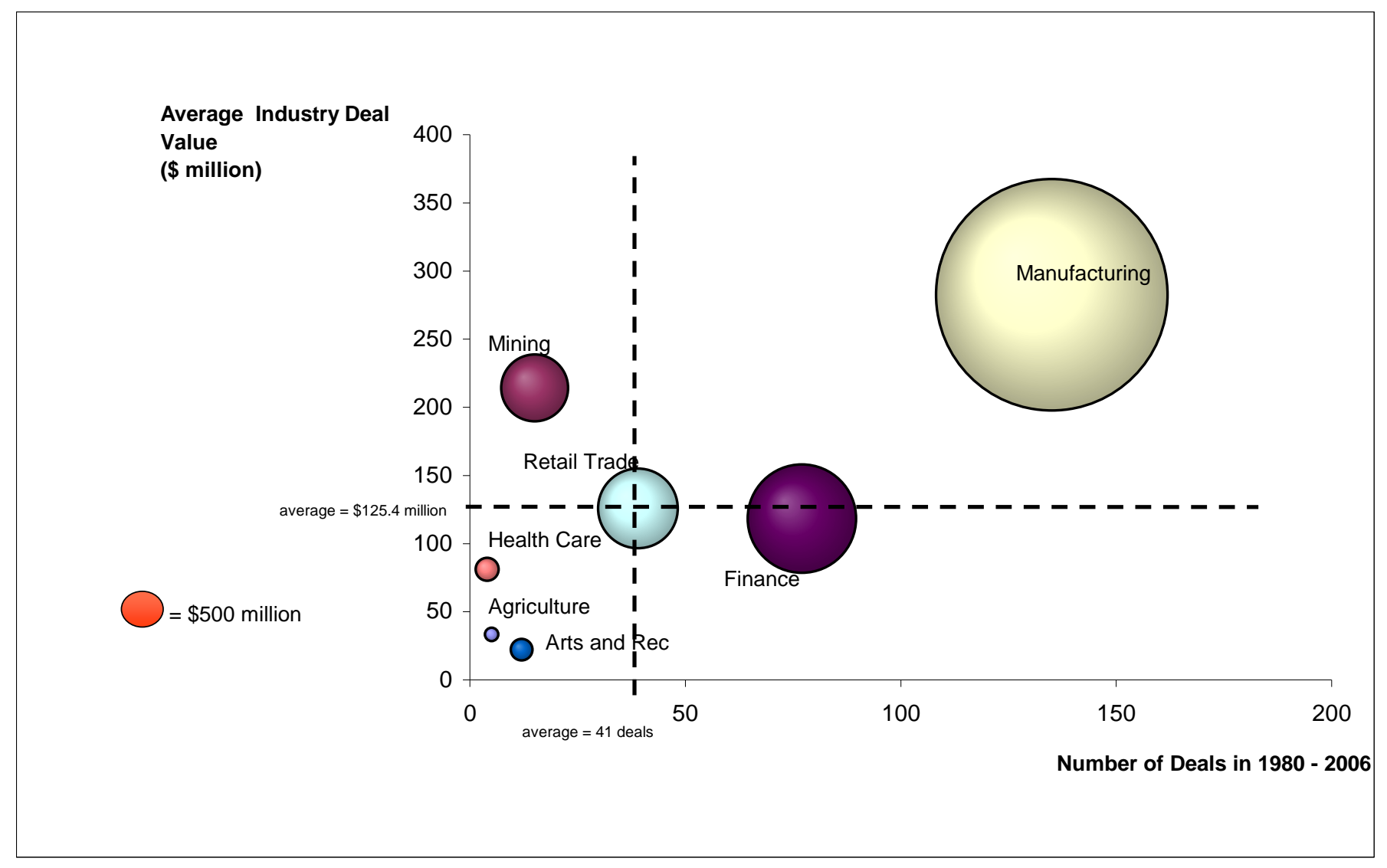

Source: SDC Thompson M\&A Database. 
Figure 3: Propensity Scores for Acquired (treated), Control (matched non-treated) and Non-treated non-weighted firms

Notes: This figure provides an illustration of the effects of our two-step Mahalanobis matching approach. The three densities plotted in the figure depict the predicted probability, i.e. propensity score, of acquisition for the acquired firms (red), the non-weighted and non-acquired firms (blue), and the Mahalanobis metric matched non-acquired firms (green).

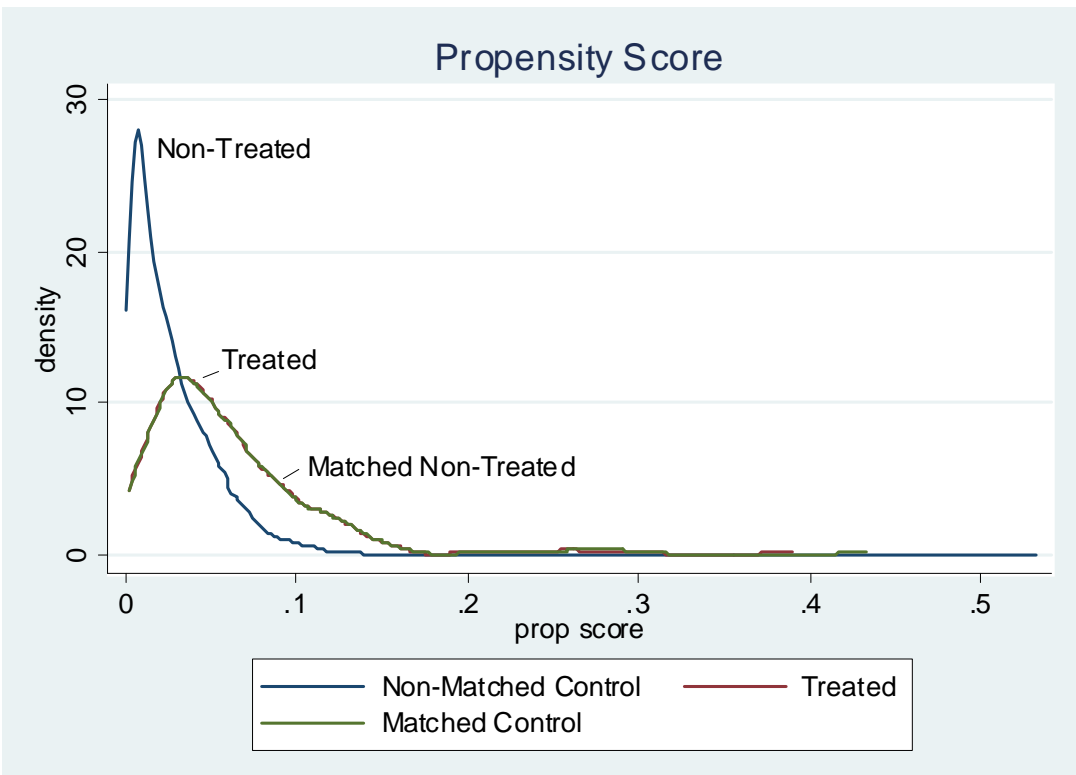

Source: Authors' calculations based on SDC Thompson M\&A Database and Compustat North America 1980 - 2006. 
Table 1: Number and Value of Acquisitions of U.S. targets by firms in Emerging Markets, 1980-2007.

Notes: This table provides a break down of transactions by acquiring country. The first column lists the name of the acquiring country. The second column presents the number of transactions. The third column presents the fraction of total transactions accounted for by the acquiring country. The final column presents the total nominal transaction value in millions of US\$ by acquiring country.

\begin{tabular}{|c|c|c|c|}
\hline Acquiring Country & $\begin{array}{l}\text { Number } \\
\text { of } \\
\text { Transactions } \\
\end{array}$ & $\begin{array}{l}\% \text { of } \\
\text { Total } \\
\text { Transactions } \\
\end{array}$ & $\begin{array}{l}\text { Nominal } \\
\text { Transaction } \\
\text { Value (\$ mil) } \\
\end{array}$ \\
\hline Hong Kong & 57 & 26.64 & 3309.572 \\
\hline Singapore & 36 & 16.82 & 6412.92 \\
\hline Mexico & 26 & 12.15 & 9346.126 \\
\hline Taiwan & 13 & 6.07 & 731.567 \\
\hline Saudi Arabia & 11 & 5.14 & 1463.797 \\
\hline South Korea & 11 & 5.14 & 319.409 \\
\hline India & 10 & 4.67 & 154.346 \\
\hline Russian Fed & 7 & 3.27 & 932.947 \\
\hline Argentina & 5 & 2.34 & 5035.794 \\
\hline China & 5 & 2.34 & 44.83 \\
\hline Bahrain & 4 & 1.87 & 1478.356 \\
\hline Kuwait & 4 & 1.87 & 5.745 \\
\hline Malaysia & 4 & 1.87 & 38.11 \\
\hline Brazil & 3 & 1.4 & 4.313 \\
\hline Egypt & 2 & 0.93 & 8.905 \\
\hline South Africa & 2 & 0.93 & 1900.151 \\
\hline Thailand & 2 & 0.93 & 27.12 \\
\hline Venezuela & 2 & 0.93 & 63.27 \\
\hline Algeria & 1 & 0.47 & 0 \\
\hline Costa Rica & 1 & 0.47 & 12.5 \\
\hline Croatia & 1 & 0.47 & 1 \\
\hline Ecuador & 1 & 0.47 & 0 \\
\hline Indonesia & 1 & 0.47 & 23 \\
\hline Nigeria & 1 & 0.47 & 6 \\
\hline Papua N Guinea & 1 & 0.47 & 2.7 \\
\hline Trinidad \& Tob & 1 & 0.47 & 0.6 \\
\hline Uganda & 1 & 0.47 & 0.68 \\
\hline Uzbekistan & 1 & 0.47 & 30.8 \\
\hline
\end{tabular}

Source: SDC Thomson M\&A Database. 
Table 2: Transaction Characteristics of the Top Twenty Emerging Country Firm Acquisitions of U.S. Targets, $1980-2007$.

Notes: The table displays the top 20 deals by acquisition value between emerging country firms and public U.S. targets based on the 214 completed transactions in our sample. The transaction characteristics include target and acquirer names, nations and industries, the announcement date, the percent acquired, transaction value and method of payment. Source: SDC Thompson -M\&A Database.

\begin{tabular}{|c|c|c|c|c|c|c|c|c|}
\hline $\begin{array}{c}\text { Date } \\
\text { Announced } \\
\end{array}$ & Target Name & Target Industry & Acquirer Name & Acquirer Industry & $\begin{array}{c}\text { Percent } \\
\text { Acquired } \\
\end{array}$ & $\begin{array}{c}\text { Transaction } \\
\text { Value } \\
\text { (\$mil) } \\
\end{array}$ & $\begin{array}{c}\text { Acquirer } \\
\text { Nation } \\
\end{array}$ & $\begin{array}{c}\text { Payment } \\
\text { Method }\end{array}$ \\
\hline 6/12/2006 & $\begin{array}{l}\text { Maverick } \\
\text { Tube Corp }\end{array}$ & $\begin{array}{l}\text { Mfg. steel tubular } \\
\text { prod }\end{array}$ & Tenaris SA & $\begin{array}{l}\text { Mfg. seamless steel } \\
\text { pipe prod }\end{array}$ & 100 & 3095.57 & Argentina & Cash \\
\hline 9/29/2000 & $\begin{array}{l}\text { Southdown } \\
\text { Inc }\end{array}$ & $\begin{array}{l}\text { Mfg. cement; } \\
\text { limestone mining }\end{array}$ & $\begin{array}{l}\text { CEMEX SA DE } \\
\text { CV }\end{array}$ & $\begin{array}{l}\text { Mfg., whl cement,ready- } \\
\text { mix prod }\end{array}$ & 100 & 2846.18 & Mexico & $\begin{array}{c}\text { Cash } \\
\text { Liabilities }\end{array}$ \\
\hline 11/22/1999 & DII Group & $\begin{array}{l}\text { Mfg. electronic } \\
\text { components }\end{array}$ & $\begin{array}{c}\text { Flextronics } \\
\text { International Ltd }\end{array}$ & Mfg. electn components & 100 & 2591.41 & Singapore & $\begin{array}{l}\text { Common } \\
\text { Stock }\end{array}$ \\
\hline 2/12/2007 & Hydril Co LP & $\begin{array}{l}\text { Mfg. oil,gas drilling } \\
\text { equip }\end{array}$ & Tenaris SA & $\begin{array}{l}\text { Mfg. seamless steel } \\
\text { pipe prod }\end{array}$ & 100 & 2212.17 & Argentina & Cash \\
\hline $11 / 20 / 2006$ & $\begin{array}{l}\text { Oregon Steel } \\
\text { Mills Inc }\end{array}$ & Mfg. steel prod & Evraz Group SA & Mfg. whl steel & 90.87 & 2087.97 & $\begin{array}{l}\text { Russian } \\
\text { Fed }\end{array}$ & Cash \\
\hline 2/28/1995 & $\begin{array}{c}\text { Maxus } \\
\text { Energy Corp }\end{array}$ & $\begin{array}{c}\text { Oil and gas } \\
\text { exploration, prodn }\end{array}$ & YPF SA & $\begin{array}{l}\text { Oil and gas } \\
\text { exploration,prodn }\end{array}$ & 100 & 1843.82 & Argentina & $\begin{array}{c}\text { Cash } \\
\text { Liabilities }\end{array}$ \\
\hline 2/10/2004 & ChipPAC Inc & Mfg. semiconductors & $\begin{array}{l}\text { ST Assembly Test } \\
\text { Services Ltd }\end{array}$ & $\begin{array}{l}\text { Mfg. semiconductor } \\
\text { testing }\end{array}$ & 100 & 1458.68 & Singapore & $\begin{array}{l}\text { Amer. Dep. } \\
\text { Receipt }\end{array}$ \\
\hline $6 / 19 / 2000$ & $\begin{array}{l}\text { United Asset } \\
\text { Mgmt. Corp }\end{array}$ & $\begin{array}{c}\text { Investment } \\
\text { management services }\end{array}$ & $\begin{array}{c}\text { Old Mutual South } \\
\text { Africa }\end{array}$ & Insurance company & 100 & 1456.67 & $\begin{array}{l}\text { South } \\
\text { Africa }\end{array}$ & Cash \\
\hline 9/24/1999 & ASARCO Inc & $\begin{array}{l}\text { Mine, smelt, refine } \\
\text { metals }\end{array}$ & $\begin{array}{c}\text { Nueva Grupo } \\
\text { Mexico SA de CV }\end{array}$ & Mining invt. holding co. & 90.48 & 1073.27 & Mexico & Cash \\
\hline 6/23/1999 & $\begin{array}{c}\text { VoiceStream } \\
\text { Wireless Corp }\end{array}$ & $\begin{array}{c}\text { Provide cellular } \\
\text { services }\end{array}$ & $\begin{array}{c}\text { Hutchison } \\
\text { Whampoa Ltd }\end{array}$ & Pvd telecom svcs & 6.03 & 957 & $\begin{array}{l}\text { Hong } \\
\text { Kong }\end{array}$ & Cash \\
\hline
\end{tabular}




\begin{tabular}{|c|c|c|c|c|c|c|c|c|}
\hline $\begin{array}{c}\text { Date } \\
\text { Announced } \\
\end{array}$ & Target Name & Target Industry & Acquirer Name & Acquirer Industry & $\begin{array}{c}\text { Percent } \\
\text { Acquired } \\
\end{array}$ & $\begin{array}{c}\text { Transaction } \\
\text { Value } \\
\text { (\$mil) } \\
\end{array}$ & $\begin{array}{c}\text { Acquirer } \\
\text { Nation } \\
\end{array}$ & $\begin{array}{l}\text { Payment } \\
\text { Method } \\
\end{array}$ \\
\hline 4/14/1997 & APL Ltd & $\begin{array}{l}\text { Shipping,trucking } \\
\text { company }\end{array}$ & $\begin{array}{l}\text { Neptune Orient } \\
\text { Lines Ltd }\end{array}$ & Shipping company & 100 & 878.48 & Singapore & Cash \\
\hline $1 / 25 / 2000$ & $\begin{array}{l}\text { CompUSA } \\
\text { Inc }\end{array}$ & $\begin{array}{c}\text { Own,operate } \\
\text { computer stores }\end{array}$ & $\begin{array}{l}\text { Grupo Sanborns } \\
\text { SA de CV }\end{array}$ & Mgmt hldg cia & 85.5 & 805.261 & Mexico & Cash \\
\hline 7/15/1987 & $\begin{array}{l}\text { Marine } \\
\text { Midland } \\
\text { Banks }\end{array}$ & $\begin{array}{l}\text { Bank holding } \\
\text { company }\end{array}$ & HSBC HK & Bank (foreign) & 48.42 & 752 & $\begin{array}{l}\text { Hong } \\
\text { Kong }\end{array}$ & Cash \\
\hline 8/9/1989 & $\begin{array}{l}\text { Anchor Glass } \\
\text { Container } \\
\text { Corp }\end{array}$ & $\begin{array}{c}\text { Manufacture glass } \\
\text { containers }\end{array}$ & Vitro SA de CV & Mfg. glass containers & 96.89 & 737 & Mexico & $\begin{array}{c}\text { Cash } \\
\text { Liabilities }\end{array}$ \\
\hline 1/30/1997 & $\begin{array}{c}\text { AST } \\
\text { Research Inc }\end{array}$ & $\begin{array}{l}\text { Mfg. computers;dvlp } \\
\text { software }\end{array}$ & $\begin{array}{c}\text { Samsung } \\
\text { Electronics Co } \\
\text { Ltd }\end{array}$ & Mfg.,whl electn prod & 55.28 & 495.8 & $\begin{array}{l}\text { South } \\
\text { Korea }\end{array}$ & $\begin{array}{c}\text { Cash } \\
\text { Liabilities }\end{array}$ \\
\hline $5 / 7 / 2001$ & Proxicom Inc & $\begin{array}{c}\text { Pvd e-bus } \\
\text { consulting,dvlp svc }\end{array}$ & $\begin{array}{l}\text { Dimension Data } \\
\text { PLC }\end{array}$ & Pvd info tech svcs & 100 & 443.481 & $\begin{array}{l}\text { South } \\
\text { Africa }\end{array}$ & Cash \\
\hline 4/15/2005 & $\begin{array}{l}\text { Brookstone } \\
\text { Inc }\end{array}$ & Own,op novelty stores & $\begin{array}{l}\text { OSIM Brookstone } \\
\text { Holdings LP }\end{array}$ & Investment company & 100 & 429.656 & Singapore & Cash \\
\hline 9/24/1999 & CMGI Inc & $\begin{array}{l}\text { Pvd direct mail advg } \\
\text { svcs }\end{array}$ & $\begin{array}{l}\text { Pacific Century } \\
\text { CyberWorks Ltd }\end{array}$ & $\begin{array}{l}\text { Internet Service } \\
\text { Provider }\{\text { ISP }\}\end{array}$ & 3.4 & 377.952 & $\begin{array}{l}\text { Hong } \\
\text { Kong }\end{array}$ & $\begin{array}{c}\text { Newly Issued } \\
\text { Ordinary } \\
\text { Shares }\end{array}$ \\
\hline $11 / 20 / 2002$ & $\begin{array}{l}\text { Stillwater } \\
\text { Mining Co }\end{array}$ & $\begin{array}{l}\text { Platinum mining } \\
\text { company }\end{array}$ & $\begin{array}{c}\text { OAO MMC } \\
\text { Norilsk Nickel } \\
\text { Group }\end{array}$ & Mfg. metal prod & 51.12 & 340.9 & $\begin{array}{l}\text { Russian } \\
\text { Fed }\end{array}$ & $\begin{array}{c}\text { Cash, Other } \\
\text { Consideration }\end{array}$ \\
\hline 11/30/1993 & $\begin{array}{l}\text { Motor Coach } \\
\text { Industries Intl }\end{array}$ & $\begin{array}{c}\text { Mfg. railroad } \\
\text { cars,equipment }\end{array}$ & $\begin{array}{l}\text { Consorcio G } \\
\text { Grupo Dina'l'ads }\end{array}$ & Manufacture trucks & 100 & 334.64 & Mexico & $\begin{array}{c}\text { Dep. Share } \\
\text { Convert. } \\
\text { Deb. }\end{array}$ \\
\hline
\end{tabular}


Table 3: Number of Acquisitions of U.S. Targets by Emerging-Market Firms \& Industry Characteristics, 1980-2007.

Notes: This table presents summary statistics for U.S. target by industry from Compustat North America. The first column presents the industry code. Column 2 presents the industry description followed by the number of firm-year observations, the total number of firms in the industry and the number of firms acquired by emerging-market firms. OIBD/Assets presents the average operating income before depreciation, amortization and taxes (\$ million). The last two columns present average sales (\$ million) and employment (million) by industry.

\begin{tabular}{|c|c|c|c|c|c|c|c|c|}
\hline NAICS & Industry & $\begin{array}{c}\text { Firm-Year } \\
\text { Observations } \\
\end{array}$ & $\begin{array}{c}\text { Total } \\
\text { number } \\
\text { of firms } \\
\end{array}$ & $\begin{array}{l}\text { Number } \\
\text { of Firms } \\
\text { Acquired } \\
\end{array}$ & $\begin{array}{c}\text { OIBD } \\
\text { (Mean) } \\
\text { \$million } \\
\end{array}$ & $\begin{array}{c}\text { Total } \\
\text { Assets } \\
\text { (Mean) } \\
\text { \$million } \\
\end{array}$ & $\begin{array}{l}\text { Sales } \\
\text { (Mean) } \\
\text { \$million } \\
\end{array}$ & $\begin{array}{l}\text { Employment } \\
\text { (Mean) } \\
\text { million } \\
\end{array}$ \\
\hline 11 & Agriculture & 2,015 & 81 & 5 & 78.64 & $1,025.18$ & $1,540.33$ & 22.12 \\
\hline 21 & $\begin{array}{l}\text { Natural } \\
\text { Resources }\end{array}$ & 13,486 & 1,287 & 12 & 61.62 & 483.75 & 296.16 & 1.68 \\
\hline 22 & Utilities & 10,085 & 495 & 2 & 24.12 & 247.60 & 184.01 & 0.40 \\
\hline 23 & Construction & 3,733 & 315 & 1 & 34.46 & 384.54 & 198.72 & 1.90 \\
\hline $31-33$ & Manufacturing & 92,935 & 7,604 & 118 & 94.72 & 824.18 & $1,000.49$ & 6.74 \\
\hline 42 & Wholesale Trade & 9,217 & 805 & 8 & 101.75 & $1,243.46$ & $1,509.49$ & 7.02 \\
\hline $44-45$ & Retail Trade & 10,802 & 978 & 16 & 77.87 & 743.30 & $1,475.87$ & 7.76 \\
\hline $48-49$ & $\begin{array}{l}\text { Transportation \& } \\
\text { Warehousing }\end{array}$ & 6,417 & 576 & 10 & 251.86 & $2,886.27$ & $2,441.86$ & 14.35 \\
\hline 51 & Information & 22,753 & 2,627 & 30 & 201.39 & $1,754.11$ & 737.93 & 3.21 \\
\hline 52 & $\begin{array}{l}\text { Finance \& } \\
\text { Insurance }\end{array}$ & 30,786 & 4,828 & 20 & $2,244.27$ & $65,056.48$ & $8,545.27$ & 18.72 \\
\hline 53 & Real Estate & 6,042 & 531 & 8 & 5.35 & 147.09 & 41.96 & 0.18 \\
\hline 54 & $\begin{array}{l}\text { Professional } \\
\text { Services }\end{array}$ & 10,097 & 1,050 & 6 & 31.94 & 200.14 & 168.12 & 1.07 \\
\hline 56 & $\begin{array}{l}\text { Administrative } \\
\text { Services }\end{array}$ & 4,743 & 492 & 1 & -1.67 & 20.90 & 17.80 & 0.09 \\
\hline 62 & $\begin{array}{l}\text { Health Care \& } \\
\text { Social Assistance }\end{array}$ & 4,049 & 441 & 2 & 16.42 & 121.52 & 131.32 & 2.03 \\
\hline 71 & $\begin{array}{l}\text { Arts, } \\
\text { Entertainment, \& } \\
\text { Recreation }\end{array}$ & 1,848 & 193 & 2 & 0.83 & 14.33 & 11.88 & 0.18 \\
\hline 72 & $\begin{array}{l}\text { Accommodation } \\
\text { \& Food Services }\end{array}$ & 5,245 & 469 & 10 & 17.36 & 159.18 & 167.09 & 2.59 \\
\hline 81 & Other Services & 1,126 & 115 & 8 & NA & NA & NA & NA \\
\hline
\end{tabular}




\section{Table 4: Evidence of Selection in the Three Years Preceding Acquisition}

Notes: These regressions test whether U.S. firm performance prior to acquisition is correlated with subsequent foreign ownership. The dependent variables are sales, assets, OIBD, cash, debt and employment and the independent variables include: $\mathrm{D}_{-}$foreign $\mathrm{n}_{\mathrm{t}}$ (a dummy variable which indicates those U.S. firms with foreign ownership at time $\mathrm{t}$ ), $\mathrm{D}_{-}$futureacq (a dummy variable which indicates those U.S. firms that become acquisition targets of emerging-market firms three years prior to the ownership change), and industry, region and year fixed effects. The dependent variables are expressed in log terms. All significant coefficients are in bold and indicate that foreign investors do not choose target firms at random. * indicates significance at $10 \%$; ** significant at $5 \%$; *** significant at $1 \%$. Standard errors are in parentheses.

\begin{tabular}{lcccccc}
\hline & Sales & Asset & OIBD & Cash & Debt & Employment \\
\hline D_foreign $_{\mathrm{t}}$ & $0.906^{* * *}$ & $0.952^{* * *}$ & 0.281 & $0.815^{* * *}$ & $0.896^{* * *}$ & $0.737^{* * *}$ \\
& $(0.19)$ & $(0.19)$ & $(0.21)$ & $(0.20)$ & $(0.24)$ & $(0.20)$ \\
D_futureacq & $0.898^{* * *}$ & $0.897^{* * *}$ & $0.553^{* * *}$ & $0.925^{* * *}$ & $0.753^{* * *}$ & $0.790^{* * *}$ \\
& $(0.10)$ & $(0.10)$ & $(0.11)$ & $(0.11)$ & $(0.13)$ & $(0.10)$ \\
Observations & 236223 & 244249 & 182936 & 217800 & 197547 & 161948 \\
R-squared & 0.172 & 0.231 & 0.193 & 0.197 & 0.203 & 0.186 \\
\hline
\end{tabular}

\section{Table 5: Cumulative Abnormal Stock Returns for Acquisition Targets}

Notes: The sample covers acquisitions of U.S. targets by emerging-market firms between January 1, 1980 and July 1, 2007. The day of first mention of the acquisition in SDC Thompson is taken as day ' 0 '. Abnormal gain to the U.S. target is computed as the cumulative abnormal return based on a single factor market model. The estimation period is 280 days before and up until 30 days before the event day. The CAR is the cumulative average abnormal return and is described in detail in section 4 of the paper. The Patell Z statistic is based on the Patell (1976) test that assumes cross-sectional independence. It is constructed by standardizing CAR by the respective standard errors. It follows a standard normal distribution under the null hypothesis.

\begin{tabular}{llcc} 
Days & N & $\begin{array}{c}\text { Mean } \\
\text { CAR }\end{array}$ & $\begin{array}{c}\text { Patell } \\
\text { Z }\end{array}$ \\
\hline \hline$(-3,+3)$ & 175 & $8.87 \%$ & $13.669^{* * *}$ \\
$(-1,+1)$ & 175 & $8.53 \%$ & $20.068^{* * *}$ \\
$(-10,+10)$ & 175 & $9.71 \%$ & $8.537^{* * *}$ \\
$(-20,+20)$ & 175 & $11.13 \%$ & $6.466^{* * *}$ \\
$(-30,+30)$ & 175 & $11.44 \%$ & $4.871^{* * *}$ \\
\hline \hline
\end{tabular}




\section{Table 6: Balancing Tests}

Notes: These tests check whether our matching approach is capable of grouping together relatively similar firms. The table presents the average difference in each of the covariates between the: (1) acquired firms and the unmatched non-acquired firms, and (2) the acquired firms and the matched (reweighted) non-acquired firms. Differences are normalized by the pooled standard deviation of the covariate in the two samples.

\begin{tabular}{|c|c|c|c|c|c|c|c|}
\hline Variable & Sample & $\begin{array}{l}\text { Treated } \\
\text { Mean } \\
\text { (Acquired) }\end{array}$ & $\begin{array}{l}\text { Control } \\
\text { Mean } \\
\text { (Non- } \\
\text { Acquired) }\end{array}$ & \%bias & $\begin{array}{l}\text { \%reduction } \\
\text { In bias }\end{array}$ & t-test & $\mathrm{p}>|\mathrm{t}|$ \\
\hline \multirow[t]{2}{*}{ Age } & Unmatched & 24.02 & 23.92 & 0.90 & & 0.10 & 0.92 \\
\hline & Matched & 24.02 & 24.11 & -0.70 & 20.10 & -0.05 & 0.96 \\
\hline \multirow[t]{2}{*}{ OIBD } & Unmatched & 198.92 & 306.99 & -8.70 & & -0.82 & 0.41 \\
\hline & Matched & 198.92 & 233.18 & -2.80 & 68.30 & -0.34 & 0.73 \\
\hline \multirow[t]{2}{*}{ Log Cash } & Unmatched & 2.42 & 1.90 & 20.90 & & 2.20 & 0.03 \\
\hline & Matched & 2.42 & 2.40 & 0.70 & 96.70 & 0.06 & 0.96 \\
\hline \multirow[t]{2}{*}{ Log Sales } & Unmatched & 5.38 & 4.87 & 22.60 & & 2.29 & 0.02 \\
\hline & Matched & 5.38 & 5.46 & -3.70 & 83.50 & -0.31 & 0.76 \\
\hline \multirow[t]{2}{*}{ Log Assets } & Unmatched & 5.56 & 5.27 & 12.50 & & 1.28 & 0.20 \\
\hline & Matched & 5.56 & 5.63 & -3.20 & 74.50 & -0.26 & 0.79 \\
\hline \multirow[t]{2}{*}{ Log Employment } & Unmatched & 0.52 & 0.15 & 17.50 & & 1.89 & 0.06 \\
\hline & Matched & 0.52 & 0.60 & -3.60 & 79.50 & -0.29 & 0.77 \\
\hline \multirow[t]{2}{*}{ Log Debt } & Unmatched & 3.31 & 3.06 & 8.20 & & 0.88 & 0.38 \\
\hline & Matched & 3.31 & 3.72 & -13.40 & -63.50 & -1.11 & 0.27 \\
\hline \multirow[t]{2}{*}{ Net Income } & Unmatched & 0.33 & 73.73 & -12.60 & & -1.07 & 0.29 \\
\hline & Matched & 0.33 & 23.17 & -3.90 & 68.90 & -0.42 & 0.68 \\
\hline \multirow[t]{2}{*}{ Log Net PPE } & Unmatched & 3.99 & 3.58 & 16.10 & & 1.69 & 0.09 \\
\hline & Matched & 3.99 & 4.11 & -5.00 & 69.20 & -0.40 & 0.69 \\
\hline
\end{tabular}


Table 7: Post-Acquisition Performance Characteristics (Propensity Score Matching and Difference-inDifferences)

Notes: This table documents difference-in-difference estimates for the post-acquisition performance between acquired and "matched control" firms that were not acquired. Panels A-D report post acquisition OIBD/Assets, $\log$ employment, $\log$ net PP\&E and log sales, respectively. $\mathrm{t}=\{0,5\}$ denotes the post-acqusition year. The second column presents the matched coefficient estimate. Estimates in bold indicate statistical differences in measured post-acquisition performance for acquired and matched non-acquired firms. Common support refers to the set of firms for whom the propensity score range overlaps across control (non-acquired) and treated (acquired) firms. Off support refers to the number of treated (acquired) firms whose propensity score lay above the maximum value or below the minimum value for the control (non-acquired) firms.

Panel A: Post-Acqusition Performance (OIBD/Asset)

Common Support $\quad$ Off Support

\begin{tabular}{ccccccccc} 
& & & & \multicolumn{2}{c}{ Common Support } & \multicolumn{2}{c}{ Off Support } \\
& $\begin{array}{c}\text { Matching } \\
\text { Estimate }\end{array}$ & $\begin{array}{c}\text { Bootstrapped } \\
\text { Std. Err. }\end{array}$ & Z-Stat & $\mathrm{P}>|\mathrm{z}|$ & Untreated & Treated & Untreated & Treated \\
\hline \hline \multicolumn{7}{c}{ Difference-in-Differences combined with } & Mahalanobis matching estimates & \\
\hline 0 & $\mathbf{- 0 . 0 5 8}$ & 0.035 & -1.66 & 0.097 & 4,750 & 126 & 0 & 0 \\
1 & -0.016 & 0.034 & -0.47 & 0.638 & 4,203 & 113 & 0 & 1 \\
2 & 0.015 & 0.059 & 0.26 & 0.793 & 3,788 & 100 & 0 & 0 \\
3 & -0.007 & 0.059 & -0.12 & 0.906 & 3,434 & 84 & 0 & 1 \\
4 & $\mathbf{0 . 0 8 3}$ & 0.040 & 2.04 & 0.041 & 3,060 & 72 & 0 & 0 \\
5 & $\mathbf{0 . 0 7 8}$ & 0.037 & 2.11 & 0.035 & 2,743 & 68 & 0 & 0 \\
\hline
\end{tabular}

Panel B: Post-Acqusition Employment

\begin{tabular}{ccccccccc} 
& & & & \multicolumn{2}{c}{ Common Support } & \multicolumn{2}{c}{ Off Support } \\
$\mathrm{t}$ & $\begin{array}{c}\text { Matching } \\
\text { Estimate }\end{array}$ & $\begin{array}{c}\text { Bootstrapped } \\
\text { Std. Err. }\end{array}$ & Z-Stat & $\mathrm{P}>|\mathrm{z}|$ & Untreated & Treated & Untreated & Treated \\
\hline \hline \multicolumn{7}{c}{ Difference-in-Differences combined with } & Mahalanobis matching estimates \\
\hline 0 & $\mathbf{- 0 . 0 8 9}$ & 0.051 & -1.74 & 0.081 & 3,063 & 94 & 0 & 0 \\
1 & $\mathbf{- 0 . 1 6 4}$ & 0.071 & -2.30 & 0.021 & 2,683 & 82 & 0 & 0 \\
2 & -0.202 & 0.168 & -1.20 & 0.228 & 2,345 & 74 & 0 & 0 \\
3 & -0.268 & 0.220 & -1.22 & 0.223 & 1,897 & 60 & 0 & 0 \\
4 & -0.234 & 0.199 & -1.17 & 0.240 & 1,621 & 50 & 0 & 0 \\
5 & -0.389 & 0.269 & -1.44 & 0.148 & 1,397 & 45 & 0 & 0 \\
\hline
\end{tabular}


Panel C: Post Acquisition Net PP\&E

Common Support $\quad$ Off Support

Matching Bootstrapped

\begin{tabular}{ccccccccc}
$\mathrm{t}$ & Estimate & Std. Err. & Z-Stat & $\mathrm{P}>|\mathrm{z}|$ & Untreated & Treated & Untreated & Treated \\
\hline \hline & \multicolumn{7}{c}{ Difference-in-Differences combined with Mahalanobis } & matching estimates \\
\hline 0 & $\mathbf{- 0 . 1 9 1}$ & 0.094 & -2.04 & 0.041 & 4,760 & 127 & 0 & 0 \\
1 & $\mathbf{- 0 . 2 1 3}$ & 0.129 & -1.65 & 0.098 & 4,203 & 113 & 0 & 1 \\
2 & $\mathbf{- 0 . 2 9 2}$ & 0.145 & -2.02 & 0.044 & 3,780 & 101 & 0 & 0 \\
3 & -0.158 & 0.176 & -0.90 & 0.369 & 3,422 & 85 & 0 & 1 \\
4 & -0.266 & 0.214 & -1.24 & 0.215 & 3,043 & 73 & 0 & 0 \\
5 & -0.415 & 0.259 & -1.60 & 0.109 & 2,726 & 67 & 0 & 0 \\
\hline
\end{tabular}

Panel D: Post-Acquisition Sales

Common Support $\quad$ Off Support

\begin{tabular}{ccccccccc} 
& $\begin{array}{c}\text { Matching } \\
\mathrm{E} \\
\text { Estimate }\end{array}$ & $\begin{array}{c}\text { Bootstrapped } \\
\text { Std. Err. }\end{array}$ & Z-Stat & $\mathrm{P}>|\mathrm{z}|$ & Untreated & Treated & Untreated & Treated \\
\hline \hline \multicolumn{7}{c}{ Difference-in-Differences combined with Mahalanobis matching estimates } \\
\hline 0 & $\mathbf{- 0 . 1 0 4}$ & 0.063 & -1.66 & 0.098 & 4,761 & 126 & 0 & 0 \\
1 & $\mathbf{- 0 . 2 1 5}$ & 0.084 & -2.56 & 0.011 & 4,196 & 113 & 0 & 1 \\
2 & $\mathbf{- 0 . 2 8 3}$ & 0.104 & -2.73 & 0.006 & 3,770 & 101 & 0 & 0 \\
3 & $\mathbf{- 0 . 2 3 9}$ & 0.117 & -2.05 & 0.040 & 3,425 & 85 & 0 & 1 \\
4 & -0.280 & 0.172 & -1.63 & 0.104 & 3,048 & 73 & 0 & 0 \\
5 & $\mathbf{- 0 . 3 2 3}$ & 0.159 & -2.03 & 0.042 & 2,737 & 68 & 0 & 0 \\
\hline
\end{tabular}


Table 8: Post-Acquisition Performance Characteristics (Simple Difference-in-Differences)

Notes: This table documents simple difference-in-difference estimates for the post-acquisition performance between acquired and control (non-acquired) firms. Panels A-D report post acquisition OIBD/Assets, log employment, log net PP\&E and log sales, respectively. $t=\{0,5\}$ denotes the post-acqusition year. The second column presents the simple difference-in-differences coefficient estimate. Estimates in bold indicate statistical differences in measured post-acquisition performance for acquired and non-acquired firms.

$\underline{\text { Panel A: Post-Acqusition Performance (OIBD/Asset) }}$

\begin{tabular}{ccccccc}
$\mathrm{t}$ & $\begin{array}{c}\text { Coefficient } \\
\text { Estimate }\end{array}$ & Std. Error & Z-Stat & $\mathrm{P}>|\mathrm{z}|$ & Untreated & Treated \\
\hline \hline & & \multicolumn{7}{c}{ Simple Difference-in-Differences } \\
\hline 0 & -0.061 & 0.061 & -0.99 & 0.322 & 4,750 & 126 \\
1 & 0.167 & 0.985 & 0.17 & 0.865 & 4,203 & 114 \\
2 & 0.358 & 1.287 & 0.28 & 0.781 & 3,788 & 100 \\
3 & 0.089 & 0.285 & 0.31 & 0.755 & 3,434 & 85 \\
5 & 0.209 & 0.56 & 0.37 & 0.708 & 3,060 & 72 \\
& 0.103 & 0.23 & 0.45 & 0.656 & 2,743 & 68
\end{tabular}

Panel B: Post-Acquisition Employment

\begin{tabular}{ccccccc}
$\mathrm{t}$ & $\begin{array}{c}\text { Coefficient } \\
\text { Estimate }\end{array}$ & Std. Error & Z-Stat & $\mathrm{P}>|\mathrm{z}|$ & Untreated & Treated \\
\hline \hline & & & Simple Difference-in-Differences & & 94 \\
\hline 0 & -0.092 & 0.307 & -0.30 & 0.765 & 3,063 & 82 \\
2 & -0.070 & 0.321 & -0.22 & 0.827 & 2,683 & 74 \\
3 & -0.356 & 0.333 & -1.07 & 0.285 & 2,345 & 60 \\
4 & -0.587 & 0.361 & -1.63 & 0.104 & 1,897 & 50 \\
5 & -0.524 & 0.380 & -1.38 & 0.167 & 1,621 & 45 \\
\hline
\end{tabular}

Panel C: Post Acquisition Net PP\&E

\begin{tabular}{ccccccc}
$\mathrm{t}$ & $\begin{array}{c}\text { Coefficient } \\
\text { Estimate }\end{array}$ & Std. Error & Z-Stat & $\mathrm{P}>|\mathrm{z}|$ & Untreated & Treated \\
\hline \hline & & \multicolumn{5}{c}{ Simple Difference-in-Differences } \\
\hline 0 & -0.225 & 0.326 & -0.69 & 0.489 & 4,760 & 127 \\
1 & -0.277 & 0.339 & -0.82 & 0.414 & 4,203 & 114 \\
2 & -0.350 & 0.352 & -0.99 & 0.320 & 3,780 & 101 \\
3 & -0.423 & 0.375 & -1.13 & 0.260 & 3,422 & 86 \\
4 & -0.529 & 0.396 & -1.33 & 0.182 & 3,043 & 73 \\
5 & -0.701 & 0.409 & -1.71 & 0.087 & 2,726 & 67 \\
\hline
\end{tabular}


Panel D: Post-Acquisition Sales

\begin{tabular}{ccccccc}
$\mathrm{t}$ & $\begin{array}{c}\text { Coefficient } \\
\text { Estimate }\end{array}$ & Std. Error & Z-Stat & $\mathrm{P}>|\mathrm{z}|$ & Untreated & Treated \\
\hline \hline & & & Simple Difference-in-Differences & & \\
\hline 0 & -0.063 & 0.296 & -0.21 & 0.831 & 4,761 & 126 \\
1 & -0.220 & 0.306 & -0.72 & 0.473 & 4,196 & 114 \\
2 & -0.335 & 0.315 & -1.06 & 0.288 & 3,770 & 101 \\
3 & -0.379 & 0.335 & -1.13 & 0.258 & 3,425 & 86 \\
4 & -0.460 & 0.357 & -1.29 & 0.197 & 3,048 & 73 \\
5 & -0.454 & 0.364 & -1.25 & 0.213 & 2,737 & 68 \\
\hline
\end{tabular}




\section{Table 9: Failed Transactions}

Notes: This table enumerates M\&A transactions that were announced but failed to be completed. Columns 1-3 present the target name, acquiror name and acquiror nation. Columns 4 and 5 present the dates the transactions were announced and withdrawn. Columns 6 and 7 present the change in the announced target's change in employment and sales in the year the transaction was announced.

\begin{tabular}{|c|c|c|c|c|c|c|}
\hline (1) & (2) & (3) & (4) & (5) & (6) & (7) \\
\hline Target Name & Acquiror Name & $\begin{array}{l}\text { Acquiror } \\
\text { Nation }\end{array}$ & $\begin{array}{c}\text { Date } \\
\text { Announced }\end{array}$ & $\begin{array}{c}\text { Date } \\
\text { Withdrawn }\end{array}$ & $\begin{array}{c}\text { Target } \\
\text { Change in } \\
\text { Employment }\end{array}$ & $\begin{array}{l}\text { Target } \\
\text { Change } \\
\text { in Sales }\end{array}$ \\
\hline Wits Basin & Easyknit & & & & & \\
\hline Precious & Enterprises Hldgs & & & & & \\
\hline Minerals & Ltd & Hong Kong & $11 / 29 / 2006$ & $11 / 1 / 2007$ & NA & NA \\
\hline KDI Corp & $\begin{array}{c}\text { Impala Pacific Corp } \\
\text { (Ariadne) } \\
\text { Berjaya }\end{array}$ & Hong Kong & 4/28/1986 & 8/21/1986 & -0.538 & -0.033 \\
\hline SSMC Inc & Corp(Malaysia)Bhd & Malaysia & 2/6/1989 & 3/22/1989 & NA & NA \\
\hline Aeronca Inc & $\begin{array}{c}\text { Korean Airlines Co } \\
\text { Ltd }\end{array}$ & South Korea & 6/10/1986 & 10/7/1986 & NA & NA \\
\hline $\begin{array}{l}\text { AT\&T Latin } \\
\text { America Corp }\end{array}$ & $\begin{array}{l}\text { Southern Cross } \\
\text { Latin America }\end{array}$ & Argentina & $1 / 7 / 2003$ & 9/3/2003 & NA & NA \\
\hline $\begin{array}{l}\text { American Maize- } \\
\text { Products Co }\end{array}$ & $\begin{array}{c}\text { Usaha Tegas Sdn } \\
\text { Bhd }\end{array}$ & Malaysia & 2/27/1995 & 7/14/1995 & NA & NA \\
\hline $\begin{array}{l}\text { Bear Stearns Cos } \\
\text { Inc }\end{array}$ & $\begin{array}{l}\text { Jardine Strategic } \\
\text { Holdings Ltd }\end{array}$ & Hong Kong & 9/30/1987 & 10/23/1987 & -0.046 & 0.009 \\
\hline $\begin{array}{l}\text { Cole National } \\
\text { Corp }\end{array}$ & $\begin{array}{l}\text { Moulin Intl Hldgs } \\
\text { Ltd }\end{array}$ & Hong Kong & $4 / 15 / 2004$ & $7 / 25 / 2004$ & NA & 0.173 \\
\hline CalMat Co & Investor Group & Hong Kong & 10/19/1987 & 10/30/1987 & 0.220 & 0.402 \\
\hline $\begin{array}{l}\text { FNB Rochester } \\
\text { Corp,NY }\end{array}$ & $\begin{array}{c}\text { Cukurova Holding } \\
\text { AS }\end{array}$ & Turkey & 5/9/1990 & 9/4/1990 & NA & NA \\
\hline $\begin{array}{c}\text { Friedman } \\
\text { Industries Inc }\end{array}$ & Investor & Venezuela & 11/7/1986 & $5 / 5 / 1987$ & NA & NA \\
\hline $\begin{array}{l}\text { Emerson Radio } \\
\text { Corp }\end{array}$ & $\begin{array}{l}\text { Semi-Tech(Global) } \\
\text { Co Ltd }\end{array}$ & Hong Kong & 3/15/1991 & 4/1/1992 & NA & NA \\
\hline $\begin{array}{l}\text { Metromedia } \\
\text { International } \\
\text { Group }\end{array}$ & Investor Group & UAE & $10 / 2 / 2006$ & $12 / 31 / 2006$ & -0.370 & -0.008 \\
\hline $\begin{array}{l}\text { Phoenix Medical } \\
\text { Technology Inc }\end{array}$ & $\begin{array}{c}\text { MBf } \\
\text { International(MBF } \\
\text { Hldg) }\end{array}$ & Hong Kong & 8/8/1990 & 10/4/1990 & NA & NA \\
\hline $\begin{array}{c}\text { Builders } \\
\text { Transport Inc }\end{array}$ & $\begin{array}{l}\text { TriSun Medical } \\
\text { America Inc }\end{array}$ & China & 3/19/1990 & $10 / 4 / 1990$ & NA & 0.053 \\
\hline $\begin{array}{c}\text { Tesoro } \\
\text { Petroleum Corp }\end{array}$ & $\begin{array}{l}\text { Oakville NV(Kuo } \\
\text { Invt Ltd) }\end{array}$ & Hong Kong & 5/31/1990 & 12/20/1990 & -0.057 & 0.268 \\
\hline Unocal Corp & CNOOC & China & $6 / 22 / 2005$ & $8 / 2 / 2005$ & NA & 0.224 \\
\hline $\begin{array}{l}\text { Union Texas } \\
\text { Petroleum } \\
\text { Holdings }\end{array}$ & $\begin{array}{l}\text { Chinese Petroleum } \\
\text { Corp }\{\text { CPC }\}\end{array}$ & Taiwan & 9/28/1990 & 12/19/1990 & NA & NA \\
\hline
\end{tabular}


Table 10: Robustness Checks (Propensity Score Matching and Difference-in-Differences)

Notes: This table documents difference-in-differences estimates for the post-acquisition performance between acquired and matched non-acquired control firms. Each panel reports post-acquisition OIBD/Assets, log sales and log employment. $\mathrm{t}=\{0,5\}$ denotes the post-acquisition year. Each column presents the Mahalanobis propensity score matched difference-indifferences coefficient estimate and bootstrapped standard errors based on reps=100 in parentheses.. Estimates in bold indicate statistical differences in measured post-acquisition performance for acquired and matched non-acquired firms.

\begin{tabular}{c|cc|cc|cc}
\hline \hline \multicolumn{7}{c}{ Panel A: Majority Acquisitions } \\
\hline \hline $\mathrm{t}$ & OIBD/Asset & \multicolumn{2}{|c|}{ Log Sales } & \multicolumn{2}{c}{ Log Employment } \\
\hline 0 & -0.309 & $(0.250)$ & $-\mathbf{0 . 3 5 4}$ & $(0.184)$ & -0.423 & $(0.283)$ \\
1 & 0.090 & $(0.175)$ & -0.280 & $(0.308)$ & -0.167 & $(0.457)$ \\
2 & 0.325 & $(0.423)$ & -0.694 & $(0.483)$ & 0.006 & $(0.626)$ \\
3 & -0.220 & $(0.183)$ & -0.136 & $(0.472)$ & 0.045 & $(0.691)$ \\
4 & -0.166 & $(0.168)$ & -0.455 & $(0.787)$ & -0.016 & $(1.087)$ \\
5 & -0.160 & $(0.171)$ & -0.808 & $(1.093)$ & -0.179 & $(1.452)$ \\
\hline
\end{tabular}

\begin{tabular}{c|cc|cc|cr}
\hline \hline \multicolumn{7}{|c}{ Panel B: Minority Acquisitions } \\
\hline \hline $\mathrm{t}$ & OIBD/Asset & \multicolumn{2}{c|}{ Log Sales } & \multicolumn{2}{c}{ Log Employment } \\
\hline 0 & -0.001 & $(0.024)$ & -0.086 & $(0.066)$ & -0.037 & $(0.050)$ \\
1 & -0.008 & $(0.031)$ & $-\mathbf{0 . 1 9 3}$ & $(0.083)$ & -0.116 & $(0.082)$ \\
2 & 0.012 & $(0.027)$ & $-\mathbf{0 . 2 1 5}$ & $(0.114)$ & -0.183 & $(0.162)$ \\
3 & 0.009 & $(0.069)$ & -0.208 & $(0.135)$ & -0.232 & $(0.262)$ \\
4 & $\mathbf{0 . 0 9 9}$ & $(0.053)$ & -0.231 & $(0.183)$ & -0.164 & $(0.208)$ \\
5 & $\mathbf{0 . 0 9 6}$ & $(0.040)$ & -0.269 & $(0.166)$ & -0.304 & $(0.279)$ \\
\hline
\end{tabular}

\begin{tabular}{c|cc|cc|cc}
\hline \hline \multicolumn{7}{c}{ Panel C: Cash Acquisitions } \\
\hline \hline $\mathrm{t}$ & OIBD/Asset & \multicolumn{2}{c}{ Log Sales } & \multicolumn{2}{c}{ Log Employment } \\
\hline 0 & -0.052 & $(0.039)$ & -0.099 & $(0.079)$ & $\mathbf{- 0 . 1 0 1}$ & $(0.054)$ \\
1 & 0.009 & $(0.034)$ & $-\mathbf{0 . 1 8 2}$ & $(0.092)$ & $\mathbf{- 0 . 1 4 4}$ & $(0.086)$ \\
2 & 0.031 & $(0.097)$ & $-\mathbf{0 . 2 5 5}$ & $(0.114)$ & -0.161 & $(0.178)$ \\
3 & 0.008 & $(0.074)$ & -0.216 & $(0.144)$ & -0.242 & $(0.269)$ \\
4 & $\mathbf{0 . 1 0 5}$ & $(0.051)$ & -0.271 & $(0.171)$ & -0.249 & $(0.247)$ \\
5 & $\mathbf{0 . 0 9 0}$ & $(0.043)$ & -0.293 & $(0.183)$ & -0.449 & $(0.300)$ \\
\hline
\end{tabular}




\begin{tabular}{c|cc|cc|cc}
\hline \hline \multicolumn{7}{c}{ Panel D: Manufacturing Acquisitions } \\
\hline \hline $\mathrm{t}$ & OIBD/Asset & \multicolumn{2}{|c|}{ Log Sales } & \multicolumn{2}{l}{ Log Employment } \\
\hline 0 & -0.044 & $(0.038)$ & -0.104 & $(0.091)$ & -0.045 & $(0.048)$ \\
1 & 0.005 & $(0.039)$ & -0.191 & $(0.126)$ & -0.144 & $(0.092)$ \\
2 & 0.044 & $(0.039)$ & -0.150 & $(0.128)$ & $\mathbf{- 0 . 2 9 6}$ & $(0.174)$ \\
3 & 0.084 & $(0.126)$ & -0.089 & $(0.153)$ & $\mathbf{- 0 . 4 9 0}$ & $(0.205)$ \\
4 & 0.091 & $(0.071)$ & -0.296 & $(0.253)$ & -0.464 & $(0.316)$ \\
5 & 0.069 & $(0.061)$ & -0.302 & $(0.278)$ & -0.510 & $(0.330)$ \\
\hline
\end{tabular}

Panel E: East Asian Acquirers from Hong Kong, Singapore, Taiwan and South Korea (excluding India and China)

\begin{tabular}{c|cc|cc|cc}
\hline \hline $\mathrm{t}$ & OIBD/Asset & & \multicolumn{2}{|c|}{ Log Sales } & \multicolumn{2}{|c}{ Log Employment } \\
\hline 0 & -0.101 & $(0.065)$ & $\mathbf{- 0 . 1 2 7}$ & $(0.075)$ & $\mathbf{- 0 . 1 4 8}$ & $(0.051)$ \\
1 & -0.039 & $(0.040)$ & $\mathbf{- 0 . 2 5 6}$ & $(0.087)$ & $\mathbf{- 0 . 2 7 0}$ & $(0.097)$ \\
2 & 0.016 & $(0.066)$ & $\mathbf{- 0 . 3 1 1}$ & $(0.155)$ & -0.292 & $(0.232)$ \\
3 & -0.038 & $(0.069)$ & $\mathbf{- 0 . 2 7 8}$ & $(0.159)$ & -0.430 & $(0.293)$ \\
4 & 0.076 & $(0.049)$ & $\mathbf{- 0 . 3 6 8}$ & $(0.205)$ & -0.441 & $(0.305)$ \\
5 & 0.044 & $(0.045)$ & -0.390 & $(0.263)$ & $\mathbf{- 0 . 5 8 0}$ & $(0.273)$ \\
\hline
\end{tabular}

Panel F: East Asian Acquirers including India and China

\begin{tabular}{c|cc|cc|cc}
\hline \hline $\mathrm{t}$ & OIBD/Asset & & \multicolumn{2}{|c|}{ Log Sales } & \multicolumn{2}{c}{ Log Employment } \\
\hline 0 & -0.004 & $(0.028)$ & -0.075 & $(0.100)$ & -0.003 & $(0.099)$ \\
1 & 0.013 & $(0.050)$ & -0.163 & $(0.140)$ & -0.006 & $(0.118)$ \\
2 & 0.015 & $(0.047)$ & -0.235 & $(0.125)$ & -0.071 & $(0.190)$ \\
3 & 0.034 & $(0.111)$ & -0.189 & $(0.185)$ & 0.013 & $(0.310)$ \\
4 & 0.092 & $(0.065)$ & -0.146 & $(0.247)$ & 0.168 & $(0.417)$ \\
5 & $\mathbf{0 . 1 3 1}$ & $(0.079)$ & -0.222 & $(0.221)$ & 0.082 & $(0.623)$ \\
\hline
\end{tabular}

Panel G: Horizontal Acquisitions

\begin{tabular}{c|cc|cc|cc}
\hline \hline $\mathrm{t}$ & OIBD/Asset & & \multicolumn{2}{|c|}{ Log Sales } & \multicolumn{2}{c}{ Log Employment } \\
\hline 0 & -0.033 & $(0.063)$ & -0.064 & $(0.107)$ & 0.008 & $(0.103)$ \\
1 & 0.029 & $(0.040)$ & -0.063 & $(0.193)$ & -0.159 & $(0.180)$ \\
2 & 0.084 & $(0.066)$ & -0.142 & $(0.283)$ & -0.501 & $(0.531)$ \\
3 & 0.082 & $(0.053)$ & -0.220 & $(0.289)$ & -0.669 & $(0.509)$ \\
4 & 0.008 & $(0.083)$ & -0.350 & $(0.390)$ & -0.569 & $(0.629)$ \\
5 & 0.029 & $(0.096)$ & -0.120 & $(0.519)$ & -0.327 & $(0.735)$ \\
\hline
\end{tabular}




\begin{tabular}{c|cc|cc|cr}
\hline \hline \multicolumn{7}{c}{ Panel H: Diversifying Acquisitions } \\
\hline \hline $\mathrm{t}$ & OIBD/Asset & \multicolumn{2}{c|}{ Log Sales } & \multicolumn{2}{c}{ Log Employment } \\
\hline 0 & -0.063 & $(0.043)$ & -0.111 & $(0.077)$ & $\mathbf{- 0 . 1 0 5}$ & $(0.059)$ \\
1 & -0.025 & $(0.036)$ & $-\mathbf{0 . 2 4 4}$ & $(0.084)$ & $\mathbf{- 0 . 1 6 4}$ & $(0.081)$ \\
2 & 0.003 & $(0.067)$ & $-\mathbf{0 . 3 0 4}$ & $(0.116)$ & -0.155 & $(0.174)$ \\
3 & -0.026 & $(0.076)$ & $-\mathbf{0 . 2 4 4}$ & $(0.132)$ & -0.187 & $(0.242)$ \\
4 & $\mathbf{0 . 0 9 6}$ & $(0.056)$ & -0.268 & $(0.170)$ & -0.160 & $(0.248)$ \\
5 & $\mathbf{0 . 0 8 7}$ & $(0.045)$ & $\mathbf{- 0 . 3 5 8}$ & $(0.202)$ & -0.400 & $(0.329)$ \\
\hline
\end{tabular}

\begin{tabular}{c|cc|cc|cc}
\hline \hline \multicolumn{7}{c}{ Panel I: Diversifying and Minority Acquisitions } \\
\hline \hline $\mathrm{t}$ & OIBD/Asset & \multicolumn{2}{c|}{ Log Sales } & Log Employment \\
\hline 0 & -0.027 & $(0.023)$ & -0.039 & $(0.060)$ & -0.028 & $(0.079)$ \\
1 & $\mathbf{- 0 . 0 6 2}$ & $(0.032)$ & $\mathbf{- 0 . 2 6 4}$ & $(0.093)$ & $\mathbf{- 0 . 1 7 8}$ & $(0.093)$ \\
2 & 0.022 & $(0.055)$ & $-\mathbf{0 . 2 0 6}$ & $(0.126)$ & $\mathbf{- 0 . 2 6 9}$ & $(0.150)$ \\
3 & 0.299 & $(0.273)$ & -0.164 & $(0.167)$ & -0.210 & $(0.265)$ \\
4 & 0.013 & $(0.058)$ & -0.275 & $(0.174)$ & -0.173 & $(0.231)$ \\
5 & 0.007 & $(0.079)$ & -0.181 & $(0.228)$ & -0.375 & $(0.287)$ \\
\hline
\end{tabular}

